\title{
Microbial electrolysis cells for electromethanogenesis: Materials, configurations and operations
}

\author{
Aditya Amrut Pawar ${ }^{1,5}$, Anandakrishnan Karthic ${ }^{1}$, Sangmin Lee $^{2}$, Soumya Pandit ${ }^{3^{\dagger}}$, \\ Sokhee P. Jung ${ }^{4+}$ \\ ${ }^{1}$ Amity Institute of Biotechnology, Amity University, Mumbai-Pune Expressway, Mumbai, Maharashtra 410206, India \\ ${ }^{2}$ Department of Environmental Engineering, Kongju National University, Cheonan 31080, Korea \\ ${ }^{3}$ Department of Life Sciences, School of Basic Sciences and Research, Sharda University, Greater Noida 201306, India \\ ${ }^{4}$ Department of Environment and Energy Engineering, Chonnam National University, Gwangju 61186, Korea \\ ${ }^{5}$ Department of Biological Sciences and Engineering, Netaji Subhas University of Technology, New Delhi, 110078, India
}

\begin{abstract}
Anaerobic digestion is a traditional method of producing methane-containing biogas by utilizing the methanogenic conversion of organic matter like agricultural waste and animal excreta. Recently, the application of microbial electrolysis cell (MECs) technology to a traditional anaerobic digestion system has been extensively studied to find new opportunities in increasing wastewater treatability and methane yield and producing valuable chemicals. The finding that both anodic and cathodic bacteria can synthesize methane has led to the efforts of optimizing multiple aspects like microbial species, formation of biofilms, substrate sources and electrode surface for higher production of the combustible compound MECs are very fascinating because of its ability to uptake a wide variety of raw materials including untreated wastewater (and its microbial content as biocatalysts). Extensive work in this field has established different systems of MECs for hydrogen production and biodegradation of organic compounds. This review is dedicated to explaining the operating principles and mechanism of the MECs for electromethanogenesis using different biochemical pathways. Emphasis on single- and double-chambered MECs along with reactor components is provided for a comprehensive description of the technology. Methane production using hydrogen evolution reaction and nanocatalysts has also been discussed
\end{abstract}

Keywords: Electromethanogenesis, Hydrogen evolution reaction, Microbial electrolysis cells, Nanocatalysts, Process improvement, Renewable energy production

\section{Introduction}

Since the last century, the entire world energy requirements have been powered by the use of fossil fuels such as coal, natural gas, petroleum and its products [1,2]. These non-renewable and fossil resources have a major share in the global economy. Fossil fuels are exhaustible and are currently depleting at the most rapid rate ever seen due to their increasing applications and continual usage. They are at the verge of depletion in roughly around 35 years [3]. Moreover, serious environmental threats and concerns are raised due to the emission of greenhouse gases into the atmosphere [4-6]. Increased levels of carbon dioxide $\left(\mathrm{CO}_{2}\right)$ and other toxic gases get released due to the burning of fuels which contribute to global warming and ocean acidification [7]. To overcome this alarming situation, there is a quest to explore carbon-free energy sources to provide energy most cleanly and sustainably.

To create energy in a sustainable and environmentally friendly manner, microbial electrochemical systems (MES) proves to be an efficient way [8, 9]. In simple terms, MES develop electrical energy by transforming the chemical energy obtained from waste lignocellulosic biomass and wastewater through the reduction-oxidation process by using the biological catalysts [10]. MES technology is a multidisciplinary field combining subjects of electrochemistry, material sciences, microbiology and chemical engineering [11]. In MES the oxidation of water takes place at the anode giving rise to electrons and protons which are further transported
This is an Open Access article distributed under the terms of the Creative Commons Attribution Non-Commercial License (http://creativecommons.org/licenses/by-nc/3.0/) which permits unrestricted non-commercial use, distribution, and reproduction in any medium, provided the original work is properly cited.

Copyright (C) 2022 Korean Society of Environmental Engineers
Received August 25, 2020 Accepted December 17, 2020

${ }^{\dagger}$ Corresponding author

E-mail: sokheejung@jnu.ac.kr; sokheejung@gmail.com; sounip@gmail.com Tel: +82-62-530-1857 Fax: +82-62-530-1859

ORCID: 0000-0002-3566-5649 
to the cathode in presence of (external) electric potential [12]. In the cathode region, the redox reactions take place under the presence of electroactive microbes [13]. MESs are further classified into microbial fuel cells (MFCs) [14], microbial electrolysis cells (MECs) [15], microbial desalination cells (MDCs) [16] and microbial solar cells (MSCs) [17] among others based on the configuration of the reactor, environmental conditions and products desired [18]. These types of MESs are operated by the principles of electro-microbiology used to explore the varied potential of electroactive bacteria (EAB) [19]. MFCs are known to generate electricity from organic waste streams whereas MECs requires a supply of electricity for producing hydrogen from organic waste streams [20]. MFCs are one of the important MESs to produce economically and environmentally friendly electricity, but it fails to compete with other energy sources such as hydrogen, methane, ethanol and other value-added chemical products. MECs are a capable technology to produce fuel and energy sourced from organic matter including wastewater and renewable resources (like an agricultural waste) [21]. MECs not only promises the production of renewable hydrogen and value-added products but also helps in the removal of organic compounds from wastewater [22]. Low energy input, self-sustaining microbial biocatalysts, high conversion efficiency, low cost and pollution inhibition are the remarkable characteristics of MECs [23-25]. Hydrogen developed from the MECs was the important metabolic gas product, however, in recent times, methane $\left(\mathrm{CH}_{4}\right)$ has gained attention from the scientific community [26-29].

Methane is a renewable fuel which was conventionally produced from anaerobic digestion of bio-waste [30]. However, the process takes many days to complete. The presence of methanogens in MES microbial community developed the process of collecting $\mathrm{CH}_{4}$ from cathode portion of MECs utilizing $\mathrm{CO}_{2}$ electromethanogenesis [31]. Methane is generally detected in MECs during the hydrogen production stage due to the growth of methanogens [32]. Chae et al. noted that the generation of methane varies with shift in inoculum, substrate, and reactor design [33]. Methanogens appear in the production phase of hydrogen, which lessens the hydrogen yield. Various approaches have been tried to cut down the development of methanogens microorganisms in MECs, but most of the approaches have turned out to be energy exhaustive and ineffective $[34,35]$. Instead of inhibiting the methanogens, producing methane directly through MECs have various advantages when compared to the anaerobic digestion process. Methane production and oxidation of organic matter are two different processes in MECs which provide a high content of methane in biogas [36]. Another advantage of MECs includes the production of methane in presence of ambient temperature which means heating is not required, thus MECs proves to be energy efficient. An added advantage of using MECs includes the acceptance of electrons directly from cathodes, making the process tolerant to toxic substances like ammonia [37]. Anaerobic digestion requires high organic content to make methane, while MECs develops $\mathrm{CH}_{4}$ even in a lower concentration of organic compounds [23, 38].

In this review, we highlight the growth of MECs in the methane production and how it works as a MES with help of other technologies like hydrogen evolution reaction (HER) and nanoparticles. A generalized pathway for electromethanogenesis along with its electron transfer method is delineated. Moreover, the contents like microbial species, reactor components, configuration along with the operating conditions which make up MECs are discussed intricately.

\section{Principle of MECs for Methane Production and Microbial Pathway}

MECs are the technology which is derived from MES where the external voltage is applied to overcome the thermodynamic energy barrier to drive biochemical reactions [39]. Electromethanogenesis synthesizes methane in two ways, either by direct uptake of electrons from electrode called direct electromethanogenesis (Eq. (1)), or mediated by hydrogen and other compounds such as acetate, formate which are produced and combined with carbon dioxide to form methane called as mediated or indirect electromethanogenesis (Eq. (2)) and (Eq. (3)) [40, 41].

Direct electromethanogenesis:

$$
\mathrm{CO}_{2}+8 \mathrm{H}^{+}+8 \mathrm{e}^{-} \rightarrow \mathrm{CH}_{4}+2 \mathrm{H}_{2} \mathrm{O}
$$$$
\mathrm{E}=-0.244 \mathrm{~V} \text { vs. Normal hydrogen electrode (NHE) }
$$

Indirect electromethanogenesis:

$$
2 \mathrm{H}^{+}+2 \mathrm{e}^{-} \rightarrow \mathrm{H}_{2} \quad \mathrm{E}=-0.41 \mathrm{~V} \text { vs. NHE }
$$

\begin{tabular}{|c|c|c|}
\hline Electrogenic microorganisms & Substrate & References \\
\hline Methanobacterium sp. & Municipal wastewater & [227] \\
\hline Clostridium sp. & Waste activated sludge & [112] \\
\hline Methanocorpusculum sp. & Waste activated sludge & {$[170]$} \\
\hline Methanosaeta sp. & Food waste and sewage sludge & [228] \\
\hline Geobacter sulfurreducens & Acetate & [209] \\
\hline Methanobrevibacter sp. & Anaerobic digester sludge & {$[189]$} \\
\hline Methanosaeta spp. & Alkaline pretreated sludge & [229] \\
\hline Shewanella oneidensis MR-1 & Acetate & {$[230]$} \\
\hline Geobacter sp., Methanosarcina sp. & Waste activated sludge & [231] \\
\hline Desulfuromondales sp., Pseudomonas sp. & Leachates of municipal solid waste & [149] \\
\hline Petrimonas sp., Methanocorpusculum sp. & Alkaline pretreated waste activated sludge & {$[170]$} \\
\hline
\end{tabular}

Table 1. Electroactive Bacteria (EAB) Used in MECs for Methane Production 


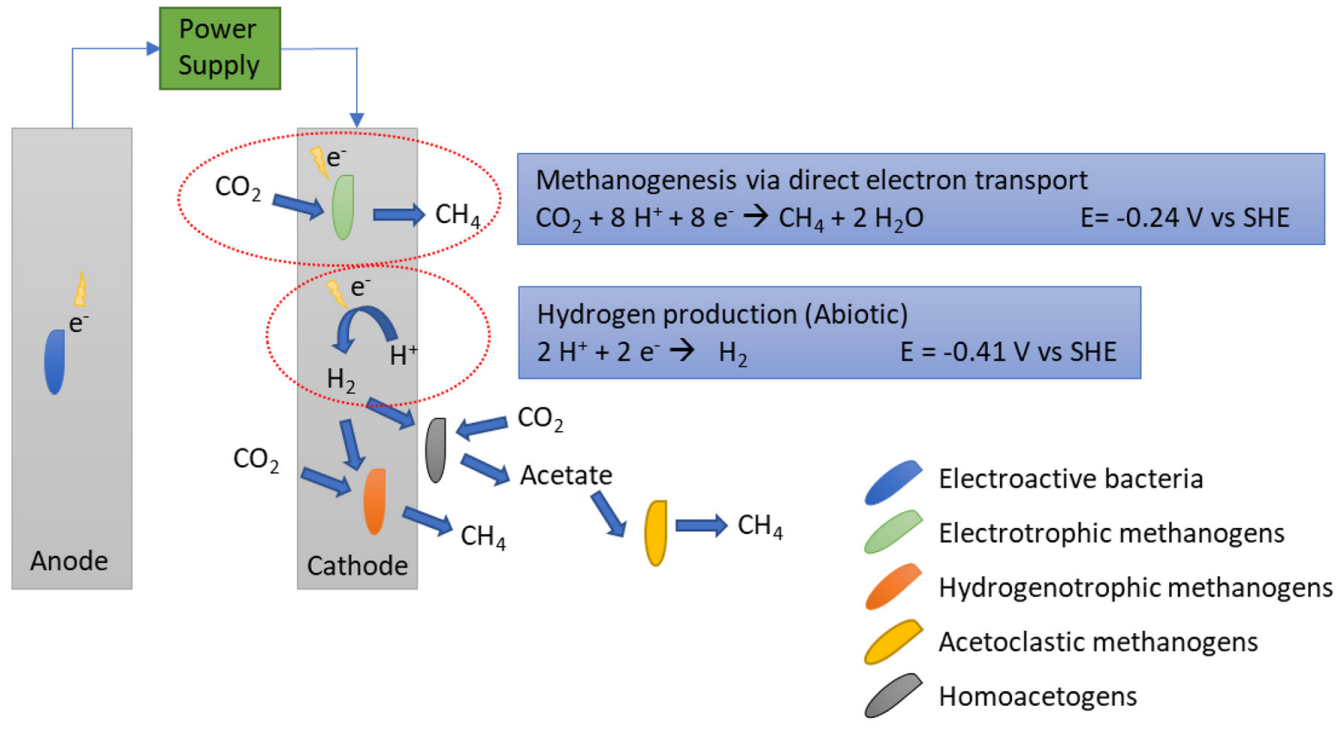

Fig. 1. Schematics of a typical MEC for electromethanogenesis.

$$
\mathrm{CO}_{2}+4 \mathrm{H}_{2} \rightarrow \mathrm{CH}_{4}+2 \mathrm{H}_{2} \mathrm{O}
$$

The hydrogenotrophic archaea have the potential to accept electrons directly from cathode catalysing only direct electromethanogenesis while, methanogenic archaea which are present in the biocathode play a crucial role in both direct and indirect electromethanogenesis, [42]. Methane producing MECs is composed of four major components: anode, biocathode, separator, electricity source (Fig. 1). In anode, oxidation reaction takes place which is necessary to provide electrons for reduction of $\mathrm{CO}_{2}$ in the biocathode region [43]. Secondly, biocathode is the important component where methane is produced by the help of microorganisms using the electrons supplied from oxidation reaction taking place in anode [44]. A separator or ion exchange membrane is necessary for migration of positively charged ions such as $\mathrm{Na}^{+}, \mathrm{K}^{+}, \mathrm{H}^{+}$from anodic chamber to cathodic chamber to keep the solution electroneutral. Lastly, externally provided electrical energy is needed to drive the reaction thermodynamically [45]. Low voltage supply $(0.2-0.8 \mathrm{~V})$ is sufficient for the bioelectrochemical reaction to produce methane [42].

\section{Hydrogen Evolution Reaction (HER)}

Due to the increasing global energy requirements, the traditional ways of power generation can lead to the degradation of the environment. The environment-friendly and sustainable production of energy is a challenge in upcoming generations [46]. The environmental concerns caused because of the fossil fuels have gained attention towards the sustainable, low-cost and less carbon emitting sources [47]. Hydrogen $\left(\mathrm{H}_{2}\right)$ is one of the striking alternative for fossil fuels in the approaching future [48]. Hydrogen is a green and clean source of energy in replacement of the traditional fossil fuels because of its recyclability and non-polluting by-products [49]. In today's scenario hydrogen production is done through the transformation of fossil fuels which is not sustainable and lead by high carbon dioxide $\left(\mathrm{CO}_{2}\right)$ emissions [50]. Hydrogen gas could be produced by electrochemical HER in the presence of low-cost catalyst coupling renewable energy sources such as wind, solar energy, geothermal heat and biomass which enhances the rate of hydrogen production [51]. It is also the most efficient and feasible method for production of hydrogen with high purity and a large quantity [52]. HER is one of the most studied electrochemical processes since the $18^{\text {th }}$ century [53]. Despite the high cost of the water electrolysis, it offers an effective method to produce highly pure hydrogen [54]. HER $\left(2 \mathrm{H}^{+}+2 \mathrm{e}^{-} \rightarrow \mathrm{H}_{2}\right)$ is a type of electrochemical cathodic reaction in which also has the potential to produce $\mathrm{H}_{2}$ $[55,56]$. HER is a prime example of two-electron transfer reaction having single catalytic intermediate which produces $\mathrm{H}_{2}$ [57]. HER may lead to the sustainability of hydrogen fuel, which is transportable, storable and applicable in the zero-emission fuel cell of combustion engines [58, 59]. Hydrogen production from the MECs is a renewable technique to produce $\mathrm{H}_{2}$ from organic materials like wastewater in presence of electric current [60, 61]. External energy in the form of applied potential is required to propel free energy of reaction negative, further producing hydrogen at cathode [62]. In this MEC process the substrate undergoes oxidation through microbes which then further produces electrons, protons and $\mathrm{CO}_{2}$ [63]. Electrons get transferred by the external circuit to the cathode, while the protons $\left(\mathrm{H}^{+}\right)$travels to the cathode through proton exchange membrane. The protons diffuse to the cathode and combine with electrons to develop hydrogen [64, 65].

\section{The Cathode and the HER}

Selection of appropriate cathode material is crucial for the MECs to produce hydrogen as it acts as the main site for HER [66]. The HER is the rate-limiting step for the MECs as it requires the transfer of mass between the gas and solid-liquid interfaces [67]. The cathode 
electrode of MECs has a structured layer which consists of a catalyst layer situated on a conductive substrate [68, 69]. The catalyst layer is composed of a fusion of catalyst, binder, substrate (e.g., made up of carbon or metal) and conductive powder such as activated carbon and carbon black. The substrate act as a support for the shape of the cathode as well as gathers the current. These cathodes are usually connected to the power supply through an external wire [70]. Functional catalysts not only reduce the activation barrier of the HER process but also determines the efficiency of $\mathrm{H}_{2}$ generation in the MECs [71]. Significant factors like production rate of hydrogen, the overall recovery of hydrogen, long-term durability and Coulombic efficiency needs to contemplated when a cathode is being assessed [72, 73]. To achieve high energy efficiency for the water-splitting electrochemical reaction use of specific catalyst is much required for minimization of overpotential and enhancement of the HER rate [74]. There is an energy barrier or resistance in the electrochemical processes for producing hydrogen from water called overpotential of the system [75]. For decreasing the energy input as well as to increase hydrogen production rate, catalyst is placed at the cathode where hydrogen is formed [76, 77]. An appropriate catalyst is required for the minimization of activation energy to reduce overpotential of the hydrogen production system, which also helps in charge transfer reaction at the surface of the cathode electrode [78, 79]. Various studies have shown the use of catalysts such as transition metals: platinum $(\mathrm{Pt})$, palladium (Pd), iridium (Ir) and rhodium (Rh) in MECs [80, 81]. Pt is a famous noble metal which efficiently catalyses hydrogen reaction [82]. Platinum-based electrodes such as brushes, rods, graphite, titanium (Ti) mesh, plates and Pt coated carbon felt are commercially available $[83,84]$. Also, the rare and lustrous metal like palladium has been used in catalysing the generation of hydrogen in hydrogen fuel cells [85]. However, using such catalytic cathodes made up of platinum and palladium have disadvantages including its high cost, negative effects on the environment, and its inactivation by chemicals like sulphides [15]. In their place, cheap metals such as iron (Fe), nickel (Ni), molybdenum (Mo), tungsten (W) can be used as cathodes in MECs [68, 86]. For improving the performance, metals could be combined with non-metal species like nitrogen, carbon, phosphides, sulphides and oxides [87]. This could also reduce the cost to produce an effective catalyst. Non-metals not only act as supportive structures which improve the charge transfer but also enhances the reduction and adsorption of hydrogen [69]. Metal alloys are also known to reduce HER activation potential such as Ni alloys and tungsten carbide [88-90].

Alternatively, biocathodes were adopted as a viable solution to catalyse HER. A biocathode is more or less an 'electron sink' which receives protons and electrons from the anodic chamber via the oxidation of organic substrates. Hence, for this purpose, electrogenic microbes are adsorbed on the cathode surface [91]. Biocathodes does not essentially require metals for the biofilm formation and their electrochemical activity [92, 93]. The species like Firmicutes, Desulfovibrio spp. and Proteobacteria phyla can be found naturally present and are reported for hydrogen production [94-96]. Sediment microbial fuel cells were shown to be converted into hydrogen- and methane-producing MES easily by reversing the potentials [97]. Hydrogen can be then recovered immediately, or it can be easily transformed into methane in presence of carbon dioxide $\left(\mathrm{CO}_{2}+\mathrm{H}_{2} \rightarrow \mathrm{CH}_{4}\right)$ by methanogenic bacteria or archaea after some days, producing up to $86 \%$ methane enriched biogas [98].

However, electrochemical systems and bioelectrochemical systems have differences. The catalyst which works well in the slightly alkaline or acidic conditions may not optimally produce $\mathrm{H}_{2}$ in near-neutral solutions [99]. This is attributed to the $\mathrm{pH}$-dependency of the metals for catalytic activity. Thus, catalysts suitable for MECs was a focus of research for HER and methanogenesis. Nanocatalysts was explored for this purpose. Many studies have been conducted using $\mathrm{MoS}_{2}$ as nanocatalyst owing to its outstanding activity due to the increased number of catalytic active edge sites [100, 101]. A better activity was observed when $\mathrm{MoS}_{2}$ was conjugated with graphene sheets for hydrogen evolution catalysis [102]. Another high catalytic activity was reported by Liu and others stating a 'nanoroll' like structure formed by $\mathrm{MoS}_{2} / \mathrm{Ti}_{3} \mathrm{C}_{2} \mathrm{Tx}$ hybrid [103]. A different Mo based 3D-open nanorod arrays was shown to be boosting the catalytic activity of HER drastically with a mere overpotential of $17 \mathrm{mV}$ [104]. Hence, nanocatalysts should be more explored for the production of hydrogen and methane.

\section{Electroactive Bacteria and its Extracellular Electron Transfer (EET) Mechanism}

\subsection{EET at Anode}

Microbial electrolysis cells are those bioelectrochemical devices which transform the chemical form of energy stored in the feedstock to high value-added chemicals such as hydrogen, methane, acetate and many more. This biological conversion takes place using the metabolic activity of few microbial species which can produce electrons or reduce of $\mathrm{CO}_{2}$. These microorganisms are called electroactive bacteria (EAB) [105]. In MECs, the interaction of microbes with other components plays a crucial role in the production of combustible products like methane. For the smooth operation of MECs, transfer of electrons from organic matter (or substrate) to the electrodes is essential [106]. Understanding this microbial extracellular electron transfer (EET) gives added advantage to develop newer strategies to engineer MECs in an effective manner [107, 108]. Microbes proficient of accepting electrons are known as electrotrophs, while exoelectrogens refers to the microbes which has the ability to transfer electrons extracellularly [109]. EAB has been found in various environments such as ocean and marine sediments, domestic wastewater and anaerobic sewage sludge [110-112]. In MECs different microbes can be developed both on the anode or cathode [113]. Gram-negative species such as Geobacter and Shewanella are usually present on the anode which oxidizes organic matter generating a flow of electrons (Fig. 2(a)) [114].

\subsubsection{EET for Gram-negative bacteria}

Two types of electron transfer take place- outside the membrane to inside and vice-versa. The initial system is MtrAB porin cytochrome complex that exists in electroactive bacteria such as Shewanella and Geobacter [115]. The second system comprises Cyc2 fused with porin cytochrome which primarily is present in iron oxidizing bacteria like A.ferroxidans under acidic conditions [116]. In general two pathways are studied as model for exocellular 


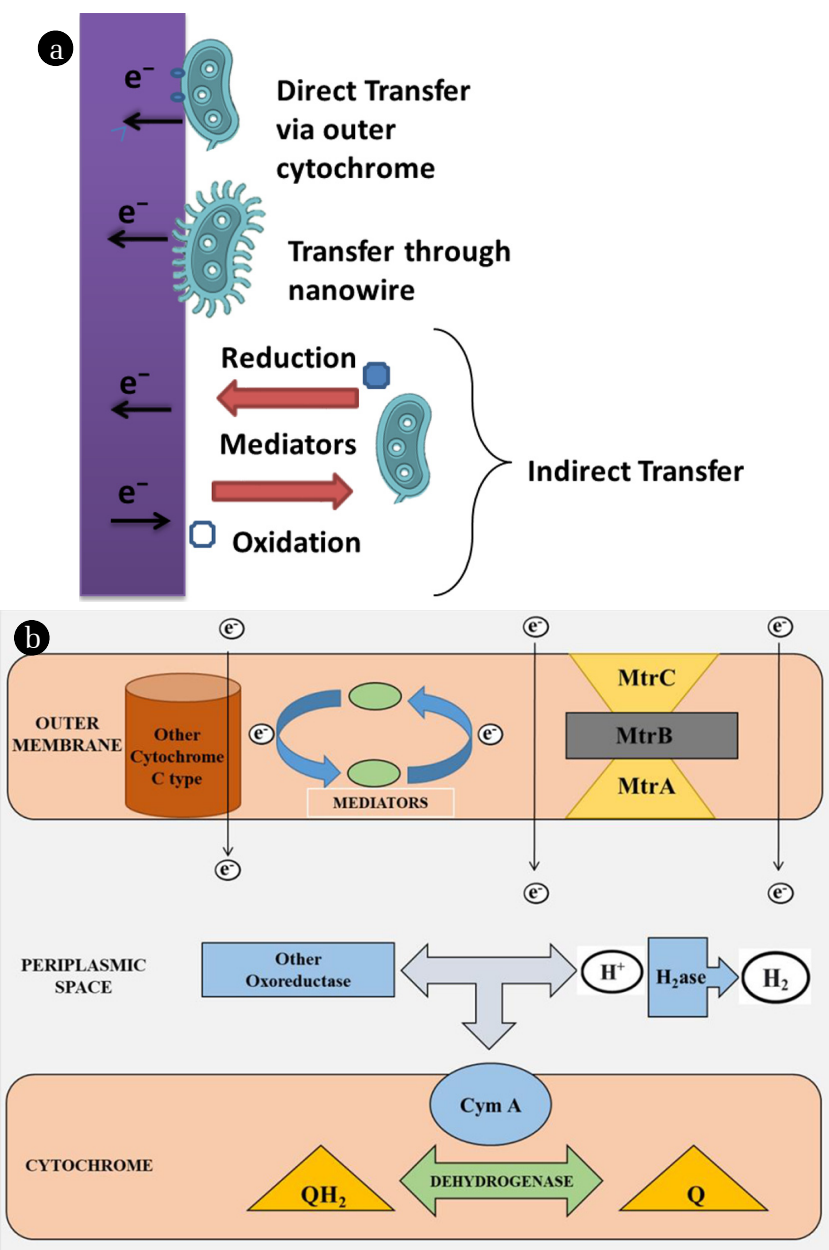

Fig. 2. (a) A schematic on different electron transfer from exoelectrogen to anode. (b) MTR pathway in Shewanella.

electron transfer that is Mtr Shewanella oneidensis which depicts MTrAB porin cytochrome system and another one is nanowire by Geobacter sulfurreducens.

\subsubsection{MTR pathway in Shewanella}

S. oneidensis MR 1- most commonly studied MTR pathway it uses $\mathrm{Fe}(\mathrm{III}), \mathrm{Mn}(\mathrm{III}), \mathrm{Mn}(\mathrm{IV})$ as a terminal electron acceptor [117]. C type cytochrome consists of an element like Cym A, FccA, Mtr A, OmcA, MtrB, MtrC, small tetraheme cytochrome and porin like MtrB. Cym A oxidation of quinol present in quinol pool in cytoplasmic membrane then it passes to the periplasmic membrane with the help of Fcc A and (small tetraheme cytochrome ) STC [118, 119]. Mtr A, B, C Cym A present in outer membrane helps in transfer of an electron to outside insoluble electron acceptors [120]. Primarily, Mtr CAB protein complex present at the outer membrane (Fig. 2(b)). Mtr c decaheme cytochrome and OmcA is a lipoprotein. Mtr B porins exist in outer membrane it helps in fixing Mtr A and Mtr C also Mtr c and OMC. A lipoprotein use as an extracellular protein present in nanowires. $S$. oneidensis MR-1 contains flavin redox mediator for extracellular electron process. Anode side reactions are more elaborately studied than cathode reaction.

\subsubsection{Nanowires - Geobacter sulfurreducens}

Geobacter sulfurreducens is a gram-negative, obligate anaerobic bacteria which comes under class of Delta Proteobacteria [121]. In G.sulfurreducens PCA, multiheme c type cytochrome component helps in the electron transport system [122]. C type cytochrome contains ImcH, CbcL, PpcA, PpcD, and omc, it comprises of B, $\mathrm{C}, \mathrm{S}$, and $\mathrm{Z}$ components [123]. ImcH and CbcL are present in the cytoplasmic side of the cell. PpcA and PpcD exist at periplasmic space and help in electron transfer further into Omcs (B, S, C, $\mathrm{S}, \mathrm{Z}$ ). This element assists in donating an electron to external electrode. Especially Omcz facilitates the transfer of an electron to an electrode [124]. Besides OmcB and OmcS component also involve largely in a reduction of iron and minerals. But it provides less output. Most electroactive bacteria like Geobacter sulfurreducens forms tremendous biofilm and has outstanding EET capacity. Approximately 40-50 micrometre thick biofilm produces $5 \mathrm{~mA}$ of current [125]. Nanowires attach physically to the electrodes using pili like organelle.

Apart from mesophiles, extremophiles also play important role in MES.

\subsubsection{Extremophilic bacteria}

Extremophiles are extraordinary, living and growing microorganisms under the most drastic conditions, Extremophiles can be divided into acidophiles, thermophiles, alkaliphiles, halophiles, psychrophiles, etc. based on stress conditions in which they reside [126].

Alkaliphiles: Alkaliphiles are extremophiles that are tolerant to high alkalinity (pH 8.5-11) [127]. Geoalkalibacter sp., alkalophilic Bacillus and $S$. oneidensis are the diverse alkalophilic strains have demonstrated good current density production in MFCs as a biocatalyst [128, 129]. Increased cell voltages were achieved in alkaline conditions in the anode and acidic conditions in a cathode chamber. The riboflavin synthesis was increased in alkalinity for $S$. oneidensis MR-1 that leads to higher current output [128].

Thermophiles: There are certain advantages while using thermophile in BES, which include the capacity to regulate the BES under hot environment which leads to an increase in catalytic activity [130, 131]. High temperatures also provide high mass and ion transfer and high solubility of the substrate. A MFC was stable for 100 days with strong Coulombic productivity when mixed culture was used $\left(55^{\circ} \mathrm{C}\right)$. The study in the $16 \mathrm{~S}$ rRNA clone library showed that 80 percent of Firmicutes are endospore-forming materials and electricity-producing. In MFC operated under thermophilic conditions, higher output power and coulombic efficiency were recorded as well as reduction of sulphates were seen [132].

Halophiles: Halophiles can reproduce in hypersaline conditions. The halophiles occur in Eubacteria in various phyla, namely, Proteobacteria, Firmicutes and Actinobacteria [133]. The application of high salt levels in MFCs has been advantageous due to improved proton transfer and increased conduction that also assists in improving the resultant energy. Therefore, halophilic EAB are useful in generating electricity and treating saline wastewater [134].

\subsubsection{Immobilization strategies on the anode: Biochemical enrich- ment strategies}

Often MES is operated with mixed consortia. Difficulty faced in 
MEC is the overgrowth of unwanted non-electrogenic population and substrate deficiency in the anode chamber. Various techniques are invented to diminish the non-electrogenic population. Pre-treatment is a convenient and the most applicable method both in anodic (MFC, MEC) and cathodic (MES) chambers [135]. Pre-treatment is done for increasing performance of electrochemical efficiency and utilization of substrate by electroactive bacteria for the production of energy and by-product [136]. There are two ways to gain product- one is the enrichment of electroactive bacteria and the second approach is to suppress the unwanted non-electrogenic microbial population [137]. Enrichment of electroactive bacteria is done by fixed anode potential, bioaugmentation mechanism and supplement of electron acceptors to increase the rate of electrochemical oxidation in anode chamber [35].

Bioaugmentation: A promising alternative approach is bioaugmentation by utilizing pure electrogen culture in mixed seeds of electroactive bacteria. The presence of non-electrogenic bacteria imposes resistance by utilising substrate and they are unable to send their extracellular electrons to the anode. On a contrary the electrogenic bacteria donates their electron directly to the anode and can be used for bioaugmentation. These electrons can be collected more effectively by anode for the current production using the simultaneous effect of pure culture and mixed inoculum by a binary electron transfer method. The pure culture of Shewanella secretes redox shuttles like flavins, which transfer electrons from bacteria to electron acceptors [138]. This helps improve the electron transfer in the electrode by the synergistic interaction of the two cultures. Through adding different substrates or alternate electron receivers to support the growth of particular bacteria, organic growth could be accomplished by increasing efficiency by introducing pure bacterial monoculture.

Regulating anodic half-cell potential: Anode potential is controlled by microbial diversity in the anodic chamber. Anode potential is correlated with electrogen biofilm, which affects microbial diversity, and the net current generation [139]. Lower anodic half-cell potential and higher cathode half-cell potential are usually crucial to yield a higher voltage in MFCs. The applied potential of $+0.2 \mathrm{~V}$ (vs.
$\mathrm{Ag} / \mathrm{AgCl}$ ) may be ideal for the growth of Geobacter sulfurreducens on anode, resulting in higher coulombic yields. Thus, the application of external voltage may be a substitute way of enriching the electrogens and reducing the start-up time of the MFC [140].

\subsection{EET at Cathode}

Electrons and protons generated during anodic oxidation is utilized at the cathode side for $\mathrm{CO}_{2}$ reduction directly or indirectly. The direct electromethanogenesis in the biocathode is carried out through redox external membrane proteins in the form of cytochromes that are in contact with the cathode [141]. In addition to cytochrome, different outer membrane proteins like the ferredoxin, rubredoxin, hydrogenase and/or formate dehydrogenase are involved in electron transfer [106]. The conductive pili (nanowires) also take part in EET of electromethanogenesis like it did in bioanode. The indirect electromethanogenesis can also be performed in three sources - i. the electrochemically or bioelectrochemically produced hydrogen; ii. formate or iii. acetate [141]. The soluble external electron shuttler or mediators in the form of riboflavins, quinones and phenazines secreted by microbes also facilitate electron transfer, consequently indirect electromethanogenesis [142].

Exoelectrogenic species like Methanosarcina and Methanosaeta which reduces $\mathrm{CO}_{2}$ to $\mathrm{CH}_{4}$ can transfer electrons directly from elemental iron [143]. A greater portion of methane is developed through the carbon dioxide reduction pathway similar to that shown in (Fig. 3) [141]. The hydrogenotrophic methanogenic archaea are found to grow on both electrodes (anode and cathode) but are mainly found at the cathode. Hydrogenotrophic methanogens such as Methanobacterium, Methanospirillum, Methanobrevibacter, Methanosarcina, Methanoculleus and Methanocorpusculum have been reported to grow on the anode suggesting the formation possibility of methane at anodes [144-149]. While on the other hand, methane can be synthesized by Methanosarcina through hydrogenotrophic and acetoclastic pathway. Methanobrevibacter, Methanoregula and Methanospirillum have been observed growing on cathode [147, 150, 151]. Species such as Methanobacterium

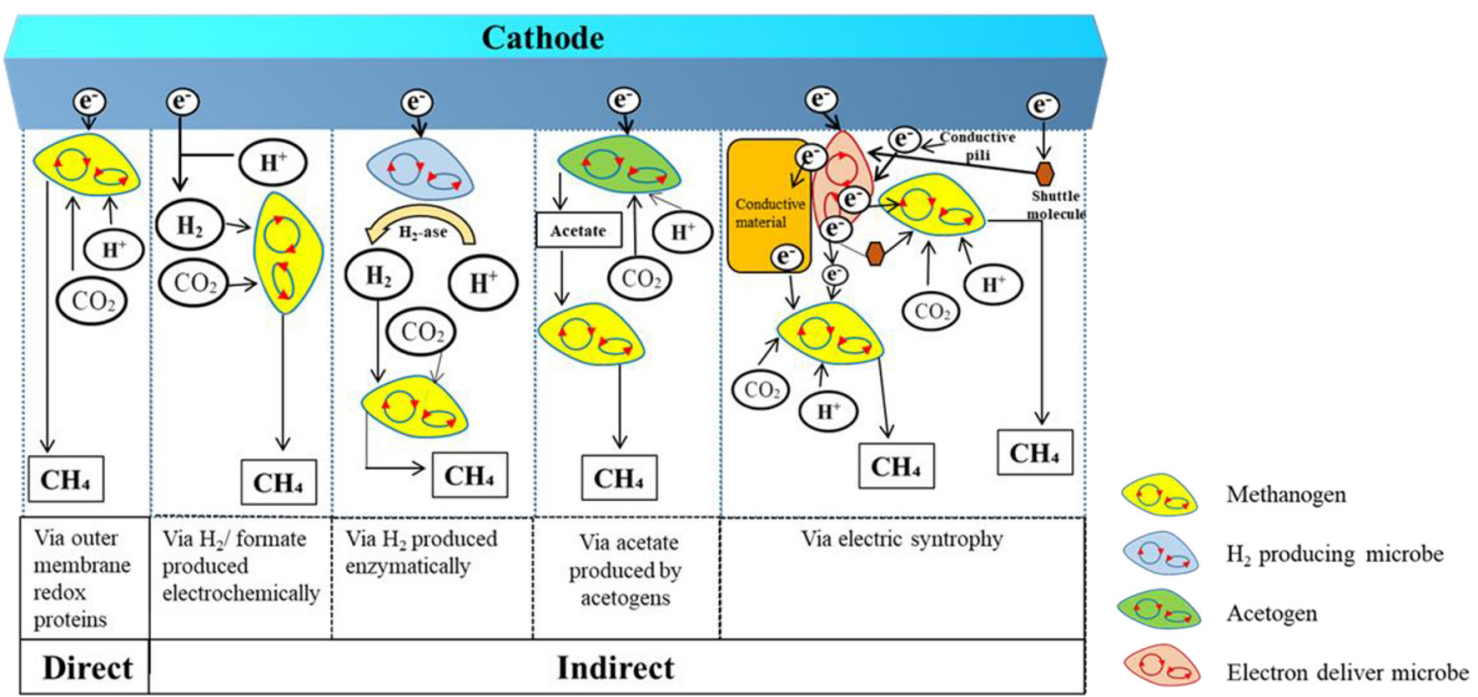

Fig. 3. A schematic diagram on microbial electron transfer scheme for production of methane at cathode. 
and Methanosaeta uses electrons to produce methane directly through the reduction of $\mathrm{CO}_{2}[152,153]$. Excessive methane production rate is reported when diverse phylotypes of methanogens come together to a definite extent and get associated with the electrode. Syntrophic relationships of the electromethanogens play a vital role in $\mathrm{CH}_{4}$ production by developing on the surface of cathode [154]. For example, methanogens like Methanocorpusculum are inefficient to arrest the electrons of a cathode and are dependent on the interspecies electron transport carried by EAB such as Acetobacterium or Geobacter [42]. The electrical syntrophy of various microbial species for producing methane depends on the type of electrode material and microbes present in culture [155]. Understanding the principle of electron transfer between EAB and an electrode is necessary to optimize the methane generation in MECs. Till date, the exact mechanism for electron transfer has not been completely proved. However, there are three known pathways which explain the generation of $\mathrm{CH}_{4}$ by MECs. The first mechanism for EET is based on direct electron transfer from bacteria to the solid electrode via outer membrane proteins such as cytochrome [156]. Another mechanism takes place in presence of soluble electron shuttle (compounds like phenazines, quinones, melanin and flavins) that carries electrons amid bacteria and the electrode through diffusive transport [157-159]. While the third mechanism states a solid component which is part of the extracellular biofilm matrix (termed as nanowires) and is conductive for electron transfer from the bacteria to the electrode as electron acceptor [160, 161].

\section{Microbial Pathways Used for Methane Production}

Any product synthesized inside an organism is a result of a biochemical reaction or a pathway. This may involve many metabolic steps involving breaking, modifying or building up of biochemical structures and compounds. Some end product of a metabolic process can be a reactant for another pathway. Here we elaborate the dedicated pathways for methane anabolism i.e. methanogenesis. There are three metabolic routes of methane production: acetoclastic, methylotrophic and hydrogenotrophic/ $\mathrm{CO}_{2}$ reduction pathway (Fig. 4). Among them, carbon dioxide reduction pathway is believed to be the major driver of the methane biosynthesis. However, other pathways gain importance when working with mixed cultures [141].

Almost, all methanogens used in methane-producing bioelectrochemical systems employ the $\mathrm{CO}_{2}$ reduction pathway except $M$. barkeri, which can use all 3 pathways for instance. Whereas species like $M$. thermophila and M. hollandica are capable of using acetoclastic and methylotrophic pathways only, respectively [162].

$\mathrm{CO}_{2}$ reduction pathway is around 4 times more widely observed than both methylotrophic and acetoclastic pathways combined. This is because $\mathrm{CO}_{2}$ and hydrogen are readily available during hydrogenotrophic methanogenesis. $\mathrm{CO}_{2}$ gets reduced and activated to formylmethanofuran where reduced ferredoxin $\left(\mathrm{Fd}_{\mathrm{red}}\right)$ is the electron donor. The second step involves the transfer of the formyl group to tetrahydromethanopterin $\left(\mathrm{H}_{4} \mathrm{MTP}\right)$. Dehydration reaction

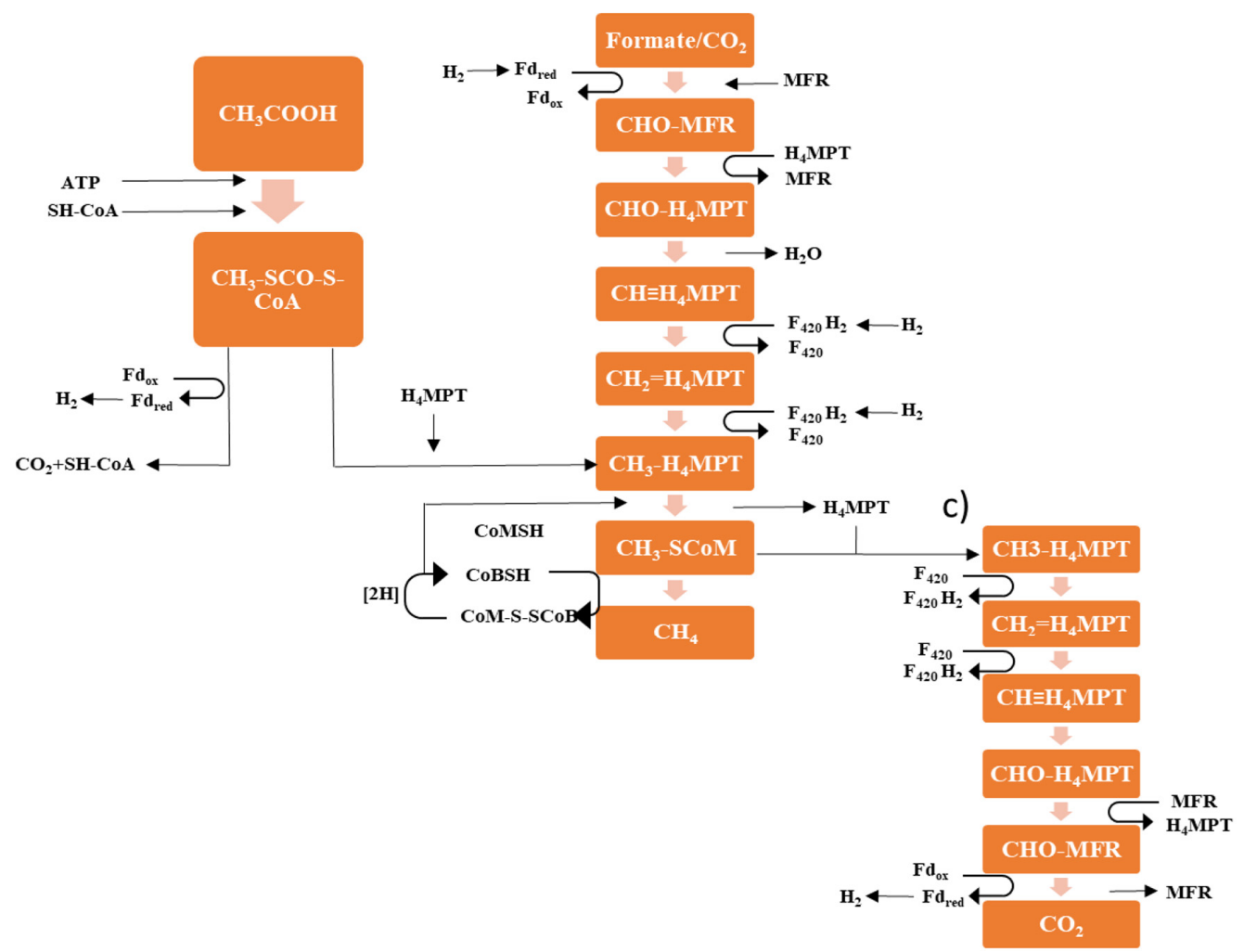

Fig. 4. Three metabolic routes implemented by microbes for electromethanogenesis. (a) Acetoclastic, (b) Hydrogenotrophic and (c) Methylotrophic methanogenesis. 
produces methylene- $\mathrm{H}_{4} \mathrm{MTP}$ subsequently reduced to methyl- $\mathrm{H}_{4} \mathrm{MTP}$ with reduced $\mathrm{F}_{420}$ as an electron donor. After the transfer of the methyl group to coenzyme M (HS-CoM), finally, methyl-CoM is reduced to $\mathrm{CH}_{4}$ with coenzyme $\mathrm{B}$ (HS-CoB) as the electron donor. The resulting CoM-S-S-CoB is reduced with $\mathrm{H}_{2}$ to recycle the coenzymes. It should be noted that some methanogens can use formate instead of hydrogen as an electron source for carbon dioxide reduction.

Methanotrix and Methanosarcina genera use acetate for methane synthesis. For acetoclastic methanogenesis to occur, acetate must be activated. This is achieved by ATP and coenzyme A by its transformation into acetyl-CoA which is further split by $\mathrm{CODH} /$ acetyl-CoA synthase complex. The $\mathrm{CH}_{3}$ group is transferred to tetrahydrosarcinapterin $\left(\mathrm{H}_{4} \mathrm{SPT}\right)$ and further converted into methane similar to the hydrogenotrophic methane production pathway.

The third route of biological methane production utilizes methyl containing substrates like methylamines, methanol, dimethyl sulphide or methanethiol. Many of methylotrophic microbes belong to Methanosarcinales. In the first step, the methyl-group from the substrate is transferred to a corrinoid protein by suitable methyltransferases and subsequently to HS-CoM by another methyltransferase, to form methyl-CoM. Simultaneously one methyl-CoM is oxidized to $\mathrm{CO}_{2}$ via the reverse hydrogenotrophic pathway thereby generating enough hydrogen to reduce three methyl-CoM to $\mathrm{CH}_{4}$ (with a by-product of proton motive force) [163].

\section{Materials Used in Constructing MECs}

The materials used to construct the MECs system are the key to determine the performance of the system. By analysing the type of materials one can know its economic value for applications in industry. While setting up a MEC system the total cost of the electrodes and membranes are also considered. Optimization of the materials used in a MEC is critical and needs to be considered earnestly for an efficient system.

\subsection{Anode}

The anode in a MECs system should have the features such as high electrical conductivity, chemical stability, anti-corrosiveness, good biocompatibility, low resistance, large surface area, strong mechanical strength, fouling resistance and scalability preferably with ease of construction and low cost [164]. These parameters are considered to be necessary for electrogenic bacteria to make effective use of anode to implement anaerobic respiration. The carbon-based anode materials are most commonly used due to its excellent biocompatibility, high electric conductivity, low overpotentials, stability and cheapness [165]. Various carbon-based anodes such as graphite fibre brush [166], graphite granules [167], graphite felt [168], carbon paper [169], carbon cloth [170], carbon fibre [171] and vitreous carbon [172] are used for the production of methane.

MFC often generates low operating voltage $\left(\mathrm{V}_{\mathrm{op}}\right)$ in comparison to the electromotive force ( $\mathrm{E}_{\text {thermo}}$ ) of the cell, often termed as thermodynamically predicted potentials which are irreversible in nature. Energy loss may occur because of several different ways such as activation loss, bacterial metabolism loss, mass transfer loss, and ohmic losses caused because of various reasons but the most common reason is excess biofilm and the organic compounds produced by the inoculum may cause biofouling of the anode thereby reducing the electron transfer from the organism to the anodic material. One such strategy is utilization of nanomaterials in anodic modification [173]. The nanomaterials facilitate the formation of electroactive bacteria and thereby promote electron transfer. Various forms of nano-metal or oxide metals, such as manganese oxide, iron oxides and titanium oxide, are used for modifications to the anode surface to improve the holding capabilities of the inoculum and to boost the electricity transport rate of the electron. Iron oxide can promote EET through two mechanism - In the form of an electrical conduit within biofilm or interface by accumulating in the cell surface [174]. Previous studies indicated the enhanced expression of c-type cytochromes responsible for improved electricity generation due to the anode surface modification with iron oxide nanoparticles. Iron oxide nanoparticles promoted the biofilm of dissimilatory iron reducing microbes like iron oxide $\left(\mathrm{Fe}_{2} \mathrm{O}_{3}\right)$. Iron oxides can be used at the anode interface to speed up the EET phase as a redox couple between Fe (II) and Fe (III). A study shows that conductive iron oxide can be used by encouraging EET in substrate degradation [175]. Titanium oxide $\left(\mathrm{TiO}_{2}\right)$ nanoparticles, due to their features like stability, abundance and low cost are used to dope carbon nanotubes. These have resulted in double the electricity generation. Au-NPs, the multi-layered gold nanoparticles, are the electron receivers providing better biofilm formation and enhanced current output with reduced electron transfer resistance [176].

Another strategy to reduce electrode overpotential in MES is to utilize conductive carbon materials like carbon nanotubes (CNT), graphene etc. Carbon nanotube has been proved to be a better alternative for anode material because of its good conductivity, biocompatibility, large surface area, and increased catalytic ability. CNTs possess some properties which are found to be strongly beneficial to improve the performance of MFCs, such as large surface area (usually up to $1,300 \mathrm{~m}^{2} \mathrm{~g}^{-1}$ ) and improve catalytic properties. Furthermore, spaces between the CNTs provide more space for microbes to grow [177]. Presently, use of graphene as anode material enormously attracted the researchers worldwide. Its honeycomb like network contains higher mechanical strength, excellent electron conductivity, increased surface area for biofilm adhesion and stable chemical ability. Its long range of П-conjugation plate shaped crumpled structure provides wide range of applications for electricity production and its storage [178]. Carbon nanotubes are known for its prominent electrical and structural properties like extensive surface area, molecule-like size, and easy functionalization with various groups which simplifies the reactions [179]. They are notably known for its hardness (comparable to diamond) and lightweight property. But carbon-based materials have a disadvantage as its intrinsic Ohmic resistance is a little high, which can cause Ohmic energy losses at a large scale. The durability of the carbon-based anode can also be a matter of concern [180]. Therefore, to further improve its performance research has been conducted to modify it. Feng et al. [181] demonstrated a modification of graphite fibre fabric with multiwalled carbon nanotube to act as a support for nickel deposition which increased the methane production rate 
by $52 \%$. Transition metals like alloys of $\mathrm{Ti} / \mathrm{Ru}[112]$ and $\mathrm{Ti} / \mathrm{RuO}_{2}$ [182] and Fe [26] were also used for methane production which also leads to decrease in operating cost of MECs. Nowadays, application of composite containing metal oxide and conductive carbon (CNT/graphene) is applied as electrode materials. For the details, readers are referred to elsewhere [183].

\subsection{Cathode}

Cathode materials play pivotal role in electromethanogenesis as well as electrohydrogenesis. The electromethanogenesis is need less energy input compared to electrohydrogenesis (-0.23 V vs SHE to $-0.41 \mathrm{~V}$ vs $\mathrm{SHE}$ ). However, extra energy input is always required to reduce cathodic overpotential. Henceforth, cathode material properties, its surface area, catalytic activity, biocompatibility play significant part in terms of MEC performance output [184]. Rozendal et al. [185] reported that the cathode accounts for $47 \%$ of the total capital expenditure for developing MECs. The overall performance of the MECs depends upon the electrodes and the materials from which they are developed. With the help of direct electron transfer or hydrogen evolution, production of methane takes place by $\mathrm{CO}_{2}$ reduction carried on both electrodes: anode and cathode [186]. Nonspontaneous reactions usually take place at the cathode region which requires specific material to catalyse reduction reaction. Expensive metals such as platinum proved its catalytic property by speeding up the reduction reaction. It is a precious transition metal having good stability. But there are many disadvantages including adverse environmental impacts and high cost [165]. Materials such as stainless steel alloys and nickel are identified as an effective alternative due to ease of availability, low cost, stability in alkaline solutions and low overpotentials. Stainless steel has been employed in developing anaerobic reactors combined with single-chamber MECs to enhance the production of methane [187]. Along with stainless steel, electrode materials developed based on alloys such as iron-graphite [26] and $\mathrm{Ti} / \mathrm{Ru}[112]$ have evolved to amplify $\mathrm{CH}_{4}$ production in the presence of sewage sludge substrate. Carbon-based cathode consisting of reticular vitreous carbon [188] and graphite [187] can also be especially beneficial for methane production. Siegert et al. [189] compared the methane production amongst precious metals (platinum, stainless steel and nickel) and nonprecious carbon-based materials (carbon brush, carbon black and plain graphite). He found that the plain graphite cathode produced higher amount of methane compared to a precious metal-based cathode. The highest yield of methane and cathode capture efficiency was observed in cathodic materials which constitute of graphite felts and carbon stick [189]. Multiwalled carbon nanotubes doped with catalytic materials such as iron phthalocyanine, ammonia, platinum, manganese oxide and nickel have also been used as alternatives of cathodic material to enhance the rate of methanogenesis [190]. Zhen et al. [191] demonstrate that plain carbon stick with a layer of graphite felt is effective in increasing methane production rate, the felt on carbon stick eventually reduced overpotential and act as 'artificial pili' for electron transfer between methanogen and cathode. Another study by Liu et al. [192] suggested granular activated carbon (GAC) as promising biocathode for promoting methanogenic biofilm which was responsible for improved methane production at cathode potential of $-0.52 \mathrm{~V}$ vs. $\mathrm{Ag} / \mathrm{AgCl}$

Table 2. Types of Membrane Used in Two-Chambered MECs

\begin{tabular}{|c|c|c|c|c|c|}
\hline Cathode & Anode & Membrane & Voltage & Methane Yield & References \\
\hline Graphite granules & $\begin{array}{l}\text { Graphite } \\
\text { granules }\end{array}$ & $\begin{array}{l}\text { Nafion } 117 \text { proton exchange } \\
\text { membrane }\end{array}$ & $-0.2 \mathrm{~V}$ & $\begin{array}{c}47.7 \pm 4.8 \mathrm{milli} \\
\text { equivalent/d (meq/d) }\end{array}$ & {$[232]$} \\
\hline Carbon stick & Carbon sticks & $\begin{array}{l}\text { CSO monovalent-cation-selective } \\
\text { exchange membrane }\end{array}$ & $-0.9 \mathrm{~V}$ & $2.30 \pm 0.34 \mathrm{~mL}$ & {$[150]$} \\
\hline Carbon stick & Platinum & $\begin{array}{l}\text { Nafion } 117 \text { proton exchange } \\
\text { membrane }\end{array}$ & $-1.4 \mathrm{~V}$ & $80.9 \mathrm{~mL} / \mathrm{L}$ & {$[191]$} \\
\hline Carbon felt & Carbon felt & Proton exchange membrane & $-0.8 \mathrm{~V}$ & $62.8 \mathrm{~mL}$ & {$[210]$} \\
\hline Granular graphite & Carbon felt & $\begin{array}{l}\text { Ultrex CMI-7000 cation exchange } \\
\text { membrane }\end{array}$ & $-800 \mathrm{mV}$ & $0.45 \pm 0.06 \mathrm{~m}^{3} \mathrm{~m}^{-3} \mathrm{~d}^{-1}$ & {$[226]$} \\
\hline Graphite carbon mesh & Graphite carbon mesh & Non-woven fabric & $0.3 \mathrm{~V}$ & $17.0 \pm 1.6 \mathrm{~L} / \mathrm{d}$ & {$[233]$} \\
\hline Graphite granules & Graphite granules & $\begin{array}{l}\text { Tubular anion exchange } \\
\text { membrane }\end{array}$ & $0.2 \mathrm{~V}$ & $300 \mathrm{meq} / \mathrm{d}$ & {$[234]$} \\
\hline Nickel steel & Reticulated vitreous carbon & $\begin{array}{l}\text { Nafion } 117 \text { proton exchange } \\
\text { membrane }\end{array}$ & $2.0 \mathrm{~V}$ & - & [197] \\
\hline Porous graphite felt & Porous graphite felt & $\begin{array}{l}\text { CMI-7000 cation exchange } \\
\text { membrane }\end{array}$ & $0.2 \mathrm{~V}$ & $0.113 \mathrm{~mol} / \mathrm{mol}$ & {$[235]$} \\
\hline Carbon doped with metals & $\begin{array}{l}\text { Carbon fibre brush electrodes } \\
\text { with titanium wire cores }\end{array}$ & Nafion membrane & $-600 \mathrm{mV}$ & $247 \pm 87 \mathrm{nmol} \mathrm{cm}^{-3} \mathrm{~d}^{-1}$ & {$[236]$} \\
\hline Graphite granules & Graphite granules & $\begin{array}{c}\text { Nafion } 117 \text { proton exchange } \\
\text { membrane }\end{array}$ & $+500 \mathrm{mV}$ & 6.4 meq $\mathrm{L}^{-1} \mathrm{~d}^{-1}$ & [209] \\
\hline Carbon felt & Carbon felt & Proton exchange membrane & $0.8 \mathrm{~V}$ & $62.8 \mathrm{~mL}$ & [210] \\
\hline Graphite blocks & Carbon fibre brushes & Nafion membrane & $-600 \mathrm{mV}$ & $250 \pm 30 \mathrm{nmol} \mathrm{cm} \mathrm{cd}^{-3}$ & [151] \\
\hline Graphite felt & Graphite felt & Cation exchange membrane & $-0.7 \mathrm{~V}$ & $\begin{array}{l}5.1 \mathrm{~L} / \mathrm{m}^{2} \text { projected } \\
\text { cathode per day }\end{array}$ & [237] \\
\hline
\end{tabular}


(-0.32 Vs. SHE). Guo et al. [193], demonstrated that 3D iron oxide nanoparticles impregnated stainless-steel cathode promoted robust biofilm provided due to high surface area and improved biocompatibility, consequently methane production increased significantly. Guo et al. [194] showed that at lower applied potential (till $0.5 \mathrm{~V}$ ), there is negligible increase in methane production rate with increase in cathode surface area to anode spatial volume (1, 2.5 and $\left.4 \mathrm{~cm}^{2} / \mathrm{cm}^{3}\right)$, nevertheless, production rate increased with higher applied voltage (0.7-0.9 V). De Vrieze et al. [195] showed that retention of methanogenic biofilm on the cathode played pivotal role in increasing methane production rate via electromethanogenesis; their study also indicated the little or null effect of applied potential on the methane production rate. Park et al. [196] found a sharp drop of around 51\% in methane generation with increasing the electrode spacing between the anode and cathode electrodes from $1 \mathrm{~cm}$ to $5 \mathrm{~cm}$ at a fixed applied voltage of $0.3 \mathrm{~V}$. Nonetheless, all these studies emphasized that high cathode properties are critical to methane production via electromethanogenesis.

\subsection{Membrane or Separator}

Membranes are the component of MECs which is used to physically divide the cathode and anode into chambers. This separator is very important to design any two-chambered MECs. Membranes prevent the mass diffusion of substrate, methane gas, hydrogen gas and microorganisms between the anodic and cathodic chambers. They only allow the conveyance of protons between electrodes. They also act as a separator to avoid short circuit in the MECs. Numerous types of membranes are recruited in MECs such as the commonly used proton exchange membrane called Nafion [197]. Anion exchange membranes for example AMI-7001 [147], CSO monovalent-cation-selective exchange membranes [150], Ultrex CMI-17000 [198] and Ultrex CMI-7000 [199] have been tested so far in the MEC reactors. It is crucial to consider the changes in $\mathrm{pH}$ gradient across the membrane due to the exchange of cations rather than the exchange of protons which lead to lower $\mathrm{pH}$ at the anode and higher $\mathrm{pH}$ at the cathode. This $\mathrm{pH}$ change can negatively affect the bacterial activity in both, the anodic and cathodic chamber [200].

\section{Nanocatalysts for Methane Production}

Nanoparticles have a very high surface area to volume ratio. This increases the surface space available for both catalytic activity and microbial interaction [201]. As it is reported that the size of the external cellular components and the pili are in the range of nanometres, nanoparticle modified electrodes can improve electron transfer and enhance chemical production rate [161]. Many properties like surface conductivity, affinity, porosity and roughness of the electrode materials can be altered with the addition of functional groups to the nanoparticles for improving cellular adherence [193, 202]. Similar to every other field where nanotechnology has helped to improve results in processes and applications it has been instrumental in bioelectrochemical systems for energy production [203].

Kim et al. [204] synthesized nickel-granular activated carbon
(Ni-GAC) nanocomposite using solution plasma and microwave-assisted methods and studied their effects on methane production in a single-chamber MEC. Along with the media, they were suspended freely in the solution. Highest methane yield (20.7 $\mathrm{mL}$ ) was obtained by Ni-GAC prepared using plasma method followed by microwave method (19.6 mL) whereas bare GAC MECs and control produced only 15.6 and $9.6 \mathrm{~mL}$, respectively. Bacterial adhesion and excellent adsorptivity is attributed to increased $\mathrm{CH}_{4}$ production. Furthermore, they reported that $\mathrm{CH}_{4}$ can be produced even in the absence of external power supply possibly through direct interspecies electron transfer (DIET) and other non-electrode reactions like the acetoclastic pathway [204].

Recently, magnetite $\left(\mathrm{Fe}_{3} \mathrm{O}_{4}\right)$ nanoparticles (NPs) were recognized to be promoting DIET in mixed culture anaerobic digestion systems. A single chamber MES was constructed with suspended synthetic medium and magnetite nanoparticles to enhance methanogenesis. With this around $215 \mathrm{~mL}$ of methane volume was obtained whereas non-nanoparticulate systems gave relatively poorer yields. The addition of the NPs to anaerobic digestion also improved the $\mathrm{CH}_{4}$ production by almost $26 \%$. The reason was discussed to be the promotion of the charge transfer process amid electrogens by magnetite NPs as an electrical conduit [205].

\section{MEC Reactor Configuration}

The configuration of the chamber(s) in MECs plays a vital character in the selection of the process to produce methane. The MEC reactor design directly influences the methane production, the energy efficiency of system and capital costs. Different reactor configurations have been propounded which consists of single-chamber and double-chamber configurations. Various chamber configurations depend upon the presence or absence of ionic exchange membranes in the system, which usually tends to divide the system into single or two chambers.

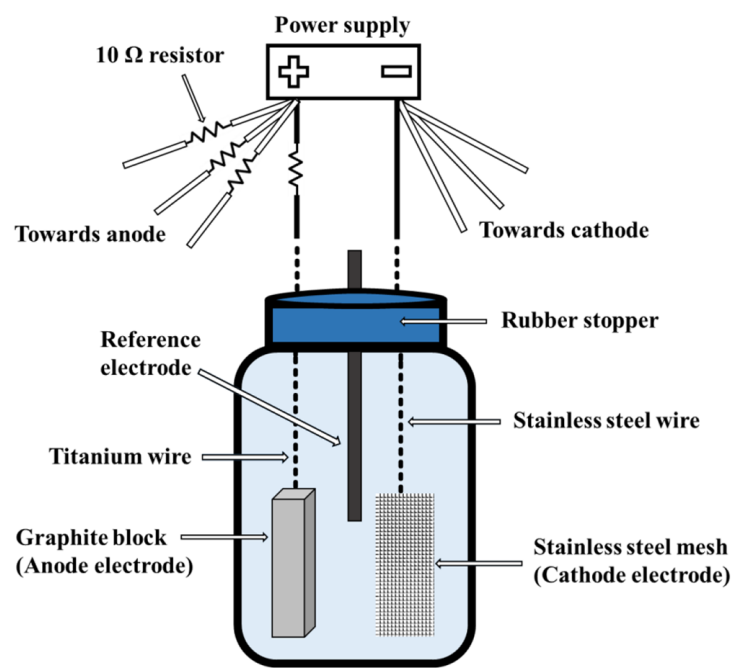

Fig. 5. A small simple single chamber membraneless MEC with a provision of parallel operation where multiple anodes and cathodes can be connected to a single power source. 


\subsection{Single-Chamber Configuration}

Single-chambered MECs are developed by detaching membranes from the double-chambered systems. The anode and the cathode, therefore, remain in the same solution of the single-chamber which helps to minimizes both the Ohmic voltage loss and $\mathrm{pH}$ gradient. This reduces the potential loss caused due to the membrane resistance. It also decreases the high capital cost and simplifies the design of the reactor. Due to this advantage, fabrication and sterilization become easy. Single chamber reactor is easy to fabricate and maintain because it does not involve membrane related complications like fouling and resistance [24]. In addition to that, the single-chamber MEC configuration encourages the multiplication of hydrogenotrophic methanogens which produces methane by consumption of hydrogen. Single chamber reactors have been reported to be constructed from materials such as stainless steel, acrylic and polypropylene. Many such designs of MECs having single-chamber configuration have been employed to produce methane. One such design includes single chamber MEC having a brush anode and flat carbon cathode. Liu et al. [206] designed a novel microbial electrolysis anaerobic digestion reactor to produce methane from waste activated sludge. It was a single chamber MEC made up of polycarbonate having a total volume of $130 \mathrm{~mL}$. The chamber consisted of an anode made from graphite brush (80 mm length, $40 \mathrm{~mm}$ diameter; $1.01 \mathrm{~m}^{2}$ surface area) and cathode developed from carbon cloth of $40 \mathrm{~mm}$ diameter. The cathode was covered with platinum catalyst layer. Methane production under this single chamber MEC configuration at an applied voltage of $0.8 \mathrm{~V}$ reached $91.8 \mathrm{~g} / \mathrm{m}^{3}$ reactor/d after 12 days of continuous batch operation. A simple small scale MEC system was developed by Siegert and his group [189]. They developed mini MECs using clear glass serum bottles having a total volume of $5 \mathrm{~mL}$. Both cathode and anode electrodes were made up of graphite plates (1.5 cm long, $1 \mathrm{~cm}$ wide and $0.32 \mathrm{~cm}$ thick, $1.5 \mathrm{~cm}^{2}$ projected surface area). A voltage of $0.7 \mathrm{~V}$ was applied to the reactor which was operated in fed-batch resulting in methane production of 0.27 $\mathrm{mL} / \mathrm{mL} \mathrm{cm}^{-2}$. Another design of single-chamber configuration comprises of tubular shaped glass reactor and non-precious metal cathode. One such reactor was developed by Hou et al. [198] made of plexiglass having a total volume of $577 \mathrm{~mL}$ (height of $15 \mathrm{~cm}$ and an inner diameter of $7 \mathrm{~cm}$ ). The anode was made up of carbon cloth while the cathode was developed from cost-effective metal material called nickel foam. The size of the anode and cathode electrode was accounted of $30 \mathrm{~cm} \times 10 \mathrm{~cm}$, while the membrane size was $30 \mathrm{~cm} \times 10.4 \mathrm{~cm}$. An optimal applied voltage of 0.95 $\mathrm{V}$ was applied to the reactor increasing methane production rate to $0.17 \mathrm{~m}^{3} / \mathrm{m}^{3}$ d. Still another type of single-chamber configuration was proposed by Guo et al. [112] who investigated the bioelectrochemical enhancement of methane production from anaerobic digestion of sewage sludge. The single-chamber membrane-free MEC reactor was manufactured using plexiglass having a total volume of $300 \mathrm{ml}$. The anode and cathode both were made up of $\mathrm{Ti} / \mathrm{Ru}$ alloy mesh plates having a distance of $2 \mathrm{~cm}$ between them. Methane productivity at applied voltages of 1.4 and $1.8 \mathrm{~V}$ was enhanced by 11.4-13.6 fold. A vertical electrode configuration employed by Katuri et al. [207] consisted of a tubular-shaped plexiglass MECs reactor of $23 \mathrm{~cm}$ length and $4.5 \mathrm{~cm}$ internal diameter (working volume of $350 \mathrm{~mL}$ ). The cathode was constructed of a nickel-based hollow-fibre membrane which was placed vertically at top of reactor and anode made up of graphite fibre brush which was positioned at the bottom of the reactor vertically. At an applied voltage of $0.7 \mathrm{~V}$, the reactor achieved methane production of around $0.028 \mathrm{~m}^{3} / \mathrm{m}^{3} / \mathrm{d}$. While Guo and team [194] configured horizontal electrode configuration of a single-chamber MECs reactor having a reactor volume of $700 \mathrm{~mL}$ made up of glass. The anode was made up of graphite fibre brushes (volume of $78.5 \mathrm{~cm}^{3}$ ). Using the different layers of circular stainless-steel mesh, stacked cathodes (diameter of $5 \mathrm{~cm}$ and $40 \mathrm{mesh}$ ) was constructed and installed in series by titanium wires having $5 \mathrm{~mm}$ interspace. The high surface area was fabricated, and the ratio of cathode surface area/ anode volume was efficient in improving the methane production when the ratio was higher than 2.5. Concentric electrodes placed in a tubular configuration has also been an alternative MEC setup for the improvement of methane production through anaerobic digestion. Feng et al. [26] used a pair of Fe tube electrode as anode and graphite pillar electrode as the cathode. The graphite pillar cathode electrode was located inside the axes of anode electrode Fe tube, which were connected to direct current (DC) power source by an electric wire. This configuration increased methane production by $22.4 \%$ at an applied voltage of $0.3 \mathrm{~V}$.

\subsection{Two-Chamber Configuration}

Two-chamber configuration is the long-established type of MECs in which the cathode and anode work individually in separate chambers which are usually divided by a membrane. In this configuration, cathode and anode are coupled by the external circuit, to which electrical energy is supplied using a power source. Various membranes have been used in two-chamber configuration MECs, in which the most common membrane used is a proton exchange membrane constructed using functional groups which only allows free protons $\left(\mathrm{H}^{+}\right)$to pass from the membrane [73]. Other membranes used in two-chamber MECs include anion-exchange membranes like AMI-7001, charge-mosaic membranes and bipolar membranes [208].

A two-chamber H-shaped reactor configuration was constructed by Cheng et al. [147] which was made up of two glass bottles of $300 \mathrm{~mL}$ each. These glass bottles were separated by the anion exchange membrane called AMI-7001 (diameter $2.9 \mathrm{~cm}$ ). The cathode and anode electrodes were made of carbon cloth $\left(14 \mathrm{~cm}^{2}\right)$ and graphite brush (diameter of 5 and $7 \mathrm{~cm}$ long) sequentially. Methane production was observed up to $656 \mathrm{mmol} / \mathrm{m}^{2} / \mathrm{d}$ at an applied voltage of $-0.7 \mathrm{~V}$ to $-1.2 \mathrm{~V}$. A new type of two-chamber MEC reactor was designed by Villano et al. [209] to generate methane from acetate using Geobacter sulfurreducens as a microbial bioanode coupled to methanogenic microbial biocathode. The reactor setup consisted of two plexiglass frames (internal dimensions of $17 \mathrm{~cm} \times$ $17 \mathrm{~cm} \times 3 \mathrm{~cm}$ ) and a proton exchange membrane Nafion 117 was placed in between the two frames. In this reactor configuration, the methane production rate was observed to be $0.018 \mathrm{~L} / \mathrm{L} / \mathrm{d}$ when the anode electrode was poised at $+0.5 \mathrm{~V}$. Zhen et al. [191] developed a two-chamber MEC (200 $\mathrm{mL}$ volume) having an anode made of platinum (23 cm length). The tubular-shaped hybridized cathode was used in the MECs which comprises of plain carbon stick having 


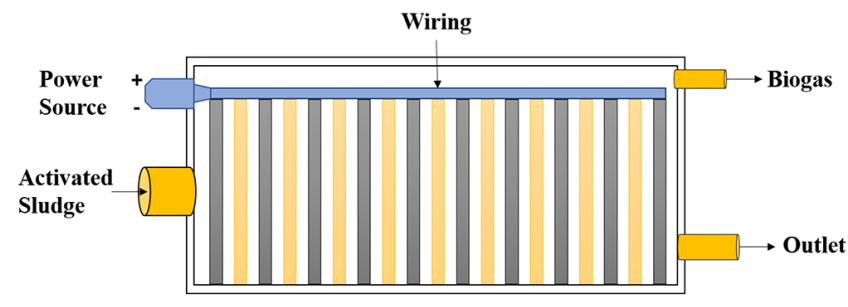

Fig. 6. 10 anodes and 9 cathodes stacked in a 33 L MEC tank as used by [154]. Each electrode compartment can be modified to contain a polyethersulfone or Nafion 117 membrane for a dual chambered configuration. Orange $=$ Cathode, Grey $=$ Anode.

a working surface area of $11 \mathrm{~cm}^{2}$. To this carbon stick, a thin layer of graphite felt was coated in a tube shape to encourage the growth of methanogens. This led to the formation of concentric biocathode two-chamber MEC configuration. Nafion 117 (working surface area of $4 \mathrm{~cm}^{2}$ ) was used as a separator between the cathode and anode electrode. At an applied potential of $-1.4 \mathrm{~V}, 80.9 \mathrm{~mL} / \mathrm{L}$ methane was produced and Coulombic efficiency of $194.4 \%$ was obtained after 24 hours of the incubation period. When compared to the single-chamber reactor, two-chamber MEC configuration is more complex. Nonetheless, drawbacks include high prices of the membrane, membrane resistance and fouling and $\mathrm{pH}$ gradient caused due to the presence of the membrane.

\section{Challenges and Factors Affecting MECs Performance}

\subsection{Applied Potential}

The applied voltage or external voltage is one of the requisite physical parameters for the performance of the MECs to manufacture methane. Adjustment in the applied voltage has a significant influence on the growth and distribution of $\mathrm{EAB}$ and further impacts methane generation [167, 210]. It is important to consider that the high values of applied electric potential could have adverse effects on the microorganism. Wang et al. reported a decrease in cell metabolism and its rupture in presence of high potentials [211]. This study proposed the need to investigate applied potentials to optimize the modifications happening in microbial activity and community. In various researches, Gram-positive bacteria were found to be mostly used as EAB in MECs combined with anaerobic digestion process for the production of methane. Due to their characteristic thick peptidoglycan cell wall having three-dimensional structure provides significant resistance to external disturbances [212]. Thus there is a need to consider optimal external voltage which should be specific for various substrates to achieve high rate production of methane. The method of voltage supply and proper consumption is needed to determine the cost of the process. Mostly in a lab-scale reactor, the direct current power supply is used, but they fail in scaling up of the methane production process [213]. Proper control of the voltage and real-time monitoring is essential for the industrialization of the process. Thus the optimal applied voltage in MECs is influenced by various factors like the type of substrate, cell configuration, electrode material and microorganisms. This dependence on different factors reveals the need to carry out voltage optimization for every MECs or BESs for better energy efficiency of the system.

\subsection{Temperature}

Temperature has a significant effect on the performance of MECs. The varying temperature in the course of MEC operation brings about the changes in microbial activity and community [214]. This changes subsequently affects the performance of the reactor. Most of the electromethanogenesis studies have been carried under two ranges of temperature, one is in ambient temperature $\left(22-25^{\circ} \mathrm{C}\right)$ while others are in mesophilic conditions $\left(30-35^{\circ} \mathrm{C}\right)[209,215]$. The temperature change affects the growth and mass transfer rate of EAB [216]. Proper understanding of the temperature parameter role is still not known completely, so there is less information by which we can know the exact effect of temperature in cell activity and microbial community. Understanding the accurate role of temperature will help in achieving high yield of methane.

\section{3. $\mathrm{pH}$}

Along with applied potential and temperature, $\mathrm{pH}$ too affects the production of methane in MECs. Most of the methane-producing MECs operate at $\mathrm{pH} 7$ due to the neutral behaviour of microorganisms [170]. This is because the $\mathrm{EAB}$ is sensitive to its surrounding $\mathrm{pH}$, even the slight fluctuation in the $\mathrm{pH}$ would cause changes in the metabolism of microbes [217]. Several other factors like ion transfer, substrate oxidation and solution conductivity too are associated with the change in $\mathrm{pH}$ directly or indirectly. Anaerobic digestion when coupled with MECs overcomes the acidification process offered by anaerobic digestion and also allows the treatment of substrates at high organic load [42].

\subsection{Substrate}

EAB oxidizes the substrate and transfers the electrons to the cathode through the anode to produce methane. Choosing the appropriate substrate is necessary to determine the final yield of methane. Organic concentration and feeding rate of the substrate are the two parameters which have a crucial role in MECs for high $\mathrm{CH}_{4}$ yield. Any organic substrate ranging from simple carbohydrates to complex fermentable substrates like wastewater and biomass can be employed in MECs [208]. The most commonly used substrate in MECs is acetate, having higher Coulombic efficiency of $91 \%$ [218]. Various types of wastewaters such as industrial (dairy, soybean and beer), domestic and municipal have been evaluated for methane production [42]. Using such waste materials as a substrate for producing methane also helps in cleaning of environment proving the MECs process to produce $\mathrm{CH}_{4}$ as environmentally friendly.

\subsection{Current Density}

Rousseau et al. [219] reviewed MECs in an electrochemical perspective. Applied current density is underutilized in the process design of MEC reactors which can largely contribute to the methane production. Stacked MECs can overcome the performance limited due to low cathode/anode ratio by increasing the current density 
[194]. Another study showed that multiple electrode configurations can both increase current generation and wastewater treatment [220]. Call and Logan developed a parallel operating single chamber MEC system as shown in (Fig. 5) which overcame many internal resistances for better conductivity and completely produced methane [61]. Sugnaux et al. [197] employed a multiple electrode reactor in both membraneless and dual-chambered configuration (Fig. 6). They reported significantly higher methane content in the produced biogas and reduced chemical oxygen demand in the outlet sludge. Therefore, focusing on the current density instead of volumetric parameters can boost methane production.

\subsection{Scale}

Latest reviews on MECs as of today discuss wastewater treatment [221], hydrogen production, valuable chemical production [222], remediation [223], electrochemical aspects of the reactor [219] and other challenges [224]. Although, widespread research has been conducted in this field, 'scale-up' of MECs to produce methane is not extensively explored. One study which used a pilot-scale $50 \mathrm{~L}$ bioelectrochemical reactor for methane synthesis concluded that instead of one big reactor, joining multiple smaller reactors will avoid large internal resistances and improve efficiency [225]. Another medium-scale (32 L) study could produce a maximum of $4.4 \mathrm{~L} \mathrm{CH}_{4}$ per metre square per day by stacking 45 cells. While integrating anaerobic digestion and MECs can improve methane production rate many manifolds with the feed of $\mathrm{CO}_{2}$ [209]. Recently, aspects related to scale-up of MECs such as electrode materials and their properties were discussed by Zakaria and Dhar [184].

\section{Conclusions and Outlook}

Due to the increased global warming around the world, the development and implementation of new green technologies for the production of methane must be environmentally friendly and sustainable. MECs have already emerged as a promising technology in the field of methane, hydrogen and wastewater treatment. Last two decades of research in the field of MECs have been noteworthy towards the practical application of MECs to produce methane. The ability to produce methane in single-stage having the capacity to work at room temperature using low-cost inputs makes it an excellent alternative for treating wastewater which can yield methane as a significant value-added product. The indirect method of methane production through highly efficient HER was elaborated. Excellent interactions like direct interspecies electron transfer by EAB have been shown in the presence of conductive carbon electrodes within the MECs reactor which further enhances the substrate digestion and yield of methane. We also discussed how the nanotechnological intervention as a catalyst has improved the methane yields and HER efficiency.

There is a need for better understanding of the electron release and transfer mechanisms between the EAB and the reactor components such as electrode and membrane. To minimize the losses caused due to the electron transfer, research and development of novel configurations in anode-cathode electrode and membrane architecture are needed to intensify the product yield. Using waste- water as the substrate for the working of MECs not only helps in producing methane but also reduces environmental pollution. The future of methane-producing MECs looks promising. Few pilot-scale reactors have been functional since last decade but still a long way is left to develop MECs for commercial applications. Besides, challenges such as large capital costs are the main barrier for the commercialization of such value-added products.

There is a need for steps of improvement for the high performance of the biofuel production. Few complications which need further studies are design and evaluation of novel and nanomaterials to improve the catalytic efficiency. Also, research and validation will be required to stimulate the adhesion of the microbes which can increase quality and quantity of biomethane. Nanoparticles in this field are promising.

In spite of having such an advantage, MECs are not a full substitute to anaerobic digestion $(\mathrm{AD})$ process largely due to its scale and far better advancement. However, MESs as a wastewater purification technology is beneficial. Therefore, MEC-AD combined MES is a more desirable technology which will be successful. Because of high cost of capital and long payback, small and medium scale $\mathrm{AD}$ are considered as economically unattractive. The electromethanogenesis in MEC-AD hybrid has the possibility to deliver high-quality biogas by reducing $\mathrm{CO}_{2}$ to gas $\mathrm{CH}_{4}$ that can lower the cost of biogas improvement.

In this review, we have provided the evaluation of the current applications and the future perspectives of using the MECs for methane production. Several conclusions were drawn regarding the production mechanism of methane, nature of electrodes, usage of $\mathrm{EAB}$ and reactor configurations.

\section{Acknowledgments}

This work was supported by Basic Science Research Program through the National Research Foundation of Korea (NRF) funded by the Ministry of Education (NRF-2018R1D1A1B07050567) and Gwangju Green Environment Center in the Ministry of Environment (17-04-10-14-12).

\section{Author Contributions}

A.A.P. (Postgraduate student) wrote the manuscript. A.K. (Postgraduate student) collected, analysed related literatures and wrote the manuscript. S.P. (Assistant Professor) wrote, reviewed and edited the manuscript and conceived the study and led the project. S.L. (Professor) reviewed and edited the manuscript. S.P.J. (Associate Professor) reviewed and edited the manuscript.

\section{References}

1. Kiani B, Mirzamohammadi S, Hosseini SH. A survey on the role of system dynamics methodology on fossil fuel resources analysis. Int. Bus. Res. 2010;3:84-93.

2. Arto I, Capellán-Pérez I, Lago R, Bueno G, Bermejo R. The energy requirements of a developed world. Energy. Sustain. 
Dev. 2016;33:1-13.

3. Shafiee S, Topal E. When will fossil fuel reserves be diminished? Energy policy. 2009;37:181-189.

4. Ramanathan V, Feng Y. Air pollution, greenhouse gases and climate change: Global and regional perspectives. Atmos Environ. 2009;43:37-50.

5. Frolkis VA, Karol IL, Kiselev AA. Global warming potential, global warming commitment and other indexes as characteristics of the effects of greenhouse gases on Earth's climate. Ecol. Indicators. 2002;2:109-121.

6. Kiehl J, Briegleb B. The relative roles of sulfate aerosols and greenhouse gases in climate forcing. Science 1993;260:311-314.

7. Doney SC, Fabry VJ, Feely RA, Kleypas JA. Ocean acidification: the other CO2 problem. Annu. Rev. Mar. Sci. 2009;1:169-192.

8. Rabaey K, Angenent L, Schroder U, Keller J. Bioelectrochemical systems: From Extracellular Electron Transfer to Biotechnological Application. IWA publishing: Place Published; 2009. p. 50-51.

9. Bajracharya S, Sharma M, Mohanakrishna G, et al. An overview on emerging bioelectrochemical systems (BESs): technology for sustainable electricity, waste remediation, resource recovery, chemical production and beyond. Renew. Energy 2016;98: 153-170.

10. Nevin KP, Woodard TL, Franks AE, Summers ZM, Lovley DR. Microbial electrosynthesis: feeding microbes electricity to convert carbon dioxide and water to multicarbon extracellular organic compounds. MBio 2010;1:e00103-00110.

11. Pant D, Singh A, Van Bogaert G, et al. Bioelectrochemical systems (BES) for sustainable energy production and product recovery from organic wastes and industrial wastewaters. RSC Adv. 2012;2:1248-1263.

12. Rabaey K, Rozendal RA. Microbial electrosynthesis - revisiting the electrical route for microbial production. Nat. Rev. Microbiol. 2010;8:706-716.

13. Wang H, Ren ZJ. A comprehensive review of microbial electrochemical systems as a platform technology. Biotechnol. Adv. 2013;31:1796-1807.

14. Rabaey K, Verstraete W. Microbial fuel cells: novel biotechnology for energy generation. Trends Biotechnol. 2005;23: 291-298.

15. Logan BE, Call D, Cheng S, et al. Microbial electrolysis cells for high yield hydrogen gas production from organic matter. Environ. Sci. Technol. 2008;42:8630-8640.

16. Cao X, Huang X, Liang P, et al. A new method for water desalination using microbial desalination cells. Environ. Sci. Technol. 2009;43:7148-7152.

17. Strik DP, Timmers RA, Helder M, et al. Microbial solar cells: applying photosynthetic and electrochemically active organisms. Trends Biotechnol. 2011;29:41-49.

18. Ali J, Sohail A, Wang L, et al. Electro-microbiology as a promising approach towards renewable energy and environmental sustainability. Energies 2018;11:1822.

19. Sydow A, Krieg T, Mayer F, Schrader J, Holtmann D. Electroactive bacteria-molecular mechanisms and genetic tools. Appl. Microbiol. Biotechnol. 2014;98:8481-8495.

20. Zhou M, Wang H, Hassett DJ, Gu T. Recent advances in microbial fuel cells (MFCs) and microbial electrolysis cells (MECs) for wastewater treatment, bioenergy and bioproducts. J. Chem.
Technol. Biotechnol. 2013;88:508-518.

21. Zhang Y, Angelidaki I. Microbial electrolysis cells turning to be versatile technology: recent advances and future challenges. Water Res. 2014;56:11-25.

22. Escapa A, Mateos R, Martínez E, Blanes J. Microbial electrolysis cells: An emerging technology for wastewater treatment and energy recovery. From laboratory to pilot plant and beyond. Renew. Sustain. Energy Rev. 2016;55:942-956.

23. Kadier A, Kalil MS, Mohamed A, et al. Microbial electrolysis cells (MECs) as innovative technology for sustainable hydrogen production: fundamentals and perspective applications. In: Sankir M, Sankir ND, eds. Hydrogen Production Technologies. Scrivener Publishing LLC; 2017. p. 407-458.

24. Liu H, Hu H, Chignell J, Fan Y. Microbial electrolysis: Novel technology for hydrogen production from biomass. Biofuels 2010;1:129-142.

25. Sun M, Sheng G-P, Mu Z-X, et al. Manipulating the hydrogen production from acetate in a microbial electrolysis cell-microbial fuel cell-coupled system. J. Power Sources. 2009;191: 338-343.

26. Feng Y, Zhang Y, Chen S, Quan X. Enhanced production of methane from waste activated sludge by the combination of high-solid anaerobic digestion and microbial electrolysis cell with iron-graphite electrode. Chem. Eng. J. 2015;259:787-794.

27. Villano M, Scardala S, Aulenta F, Majone M. Carbon and nitrogen removal and enhanced methane production in a microbial electrolysis cell. Bioresour. Technol. 2013;130:366-371.

28. Yin C, Shen Y, Yuan R, et al. Sludge-based biochar-assisted thermophilic anaerobic digestion of waste-activated sludge in microbial electrolysis cell for methane production. Bioresour. Technol. 2019;284:315-324.

29. Arvin A, Hosseini M, Amin MM, Darzi GN, Ghasemi Y. Efficient methane production from petrochemical wastewater in a single membrane-less microbial electrolysis cell: the effect of the operational parameters in batch and continuous mode on bioenergy recovery. J. Environ. Health Sci. Eng. 2019;17:305-317.

30. Gunaseelan VN. Anaerobic digestion of biomass for methane production: a review. Biomass Bioenergy. 1997;13:83-114.

31. Zhang Z, Song Y, Zheng S, et al. Electro-conversion of carbon dioxide $\left(\mathrm{CO}_{2}\right)$ to low-carbon methane by bioelectromethanogenesis process in microbial electrolysis cells: the current status and future perspective. Bioresour. Technol. 2019;279:339-349.

32. Lu L, Ren N, Zhao X, et al. Hydrogen production, methanogen inhibition and microbial community structures in psychrophilic single-chamber microbial electrolysis cells. Energy Environ. Sci. 2011;4:1329-1336.

33. Chae K-J, Choi M-J, Kim K-Y, et al. Selective inhibition of methanogens for the improvement of biohydrogen production in microbial electrolysis cells. Int. J. Hydrog. Energy. 2010;35: 13379-13386.

34. Zhu X, Siegert M, Yates MD, Logan BE. Alamethicin suppresses methanogenesis and promotes acetogenesis in bioelectrochemical systems. Appl. Environ. Microbiol. 2015;81:3863-3868.

35. Jadhav DA, Chendake AD, Schievano A, Pant D. Suppressing methanogens and enriching electrogens in bioelectrochemical systems. Bioresour. Technol. 2019;277:148-156.

36. Anwer AH, Khan MD, Khan MZ, Joshi R. Microbial 
Electrochemical Cell: An Emerging Technology for Waste Water Treatment and Carbon Sequestration. In: Oves M, Ansari M, Zain Khan M, Shahadat M, Ismail IMI, eds. Modern Age Waste Water Problems. Springer; 2020. p. 339-360.

37. Mohamed SN, Matheswaran M, Jayabalan T. Microbial electrolysis cells for converting wastes to biohydrogen. In: Rathinam NK, Sani RK, eds. Biovalorisation of Wastes to Renewable Chemicals and Biofuels. Elsevier; 2020. p. 287-301.

38. Kadier A, Kalil MS, Rai PK, et al. Microbial Electrolysis Cells (MECs) A Promising and Green Approach for Bioenergy and Biochemical Production from Waste Resources. In: Krishnaraj RN, Sani RK, eds. Bioelectrochemical Interface Engineering. John Wiley \& Sons; 2019. p. 209-234.

39. Khan M, Nizami A, Rehan M, et al. Microbial electrolysis cells for hydrogen production and urban wastewater treatment: A case study of Saudi Arabia. Appl. Energy. 2017;185:410-420.

40. Van Eerten-Jansen MC, Heijne AT, Buisman CJ, Hamelers HV. Microbial electrolysis cells for production of methane from $\mathrm{CO}_{2}$ : long-term performance and perspectives. Int. J. Energ. Res. 2012;36:809-819.

41. Nelabhotla ABT, Dinamarca C. Bioelectrochemical $\mathrm{CO}_{2}$ reduction to methane: MES integration in biogas production processes. Appl. Sci. 2019;9:1056.

42. Buitrón G, Cardeña R, Arcila JS. Bioelectrosynthesis of Methane Integrated With Anaerobic Digestion. in: SV Mohan, S Varjani, A Pandey, eds. Microbial Electrochemical Technology. Elsevier; 2019. p. 899-919.

43. Jeremiasse AW, Hamelers HV, Buisman CJ. Microbial electrolysis cell with a microbial biocathode. Bioelectrochemistry 2010;78:39-43.

44. Nam J-Y, Tokash JC, Logan BE. Comparison of microbial electrolysis cells operated with added voltage or by setting the anode potential. Int. J. Hydrogen Energ. 2011;36:10550-10556.

45. Liu D. Strategies for improving methane production from $\mathrm{CO}_{2}$ and electricity in bioelectrochemical systems [dissertation]. Wageningen: Wageningen University; 2018.

46. Chu S, Majumdar A. Opportunities and challenges for a sustainable energy future. Nature 2012;488:294-303.

47. Evans A, Strezov V, Evans TJ. Sustainability considerations for electricity generation from biomass. Renew. Sust. Energ. Rev. 2010;14:1419-1427.

48. Han G-Q, Shang X, Lu S-S, et al. Electrodeposited MoSx films assisted by liquid crystal template with ultrahigh electrocatalytic activity for hydrogen evolution reaction. Int. J. Hydrogen Energ. 2017;42:5132-5138.

49. Muradov NZ, Veziroğlu TN. "Green" path from fossil-based to hydrogen economy: an overview of carbon-neutral technologies. Int. J. Hydrogen. Energy. 2008;33:6804-6839.

50. Tachibana Y, Vayssieres L, Durrant JR. Artificial photosynthesis for solar water-splitting. Nat. Photon. 2012;6:511-518.

51. Ojha K, Saha S, Dagar P, Ganguli AK. Nanocatalysts for hydrogen evolution reactions. Phys. Chem. Chem. Phys. 2018;20: 6777-6799.

52. Chen HM, Chen CK, Liu R-S, et al. Nano-architecture and material designs for water splitting photoelectrodes. Chem. Soc. Rev. 2012;41:5654-5671.

53. Lasia A. Hydrogen evolution reaction. In: Vielstich W, Lamm
A, Gasteiger HA, Yokokawa H, eds. Handbook of fuel cells. 2010.

54. Kumar SS, Himabindu V. Hydrogen production by PEM water electrolysis-A review. Mater. Sci. Energy Technol. 2019;2: 442-454.

55. Jiao Y, Zheng Y, Jaroniec M, Qiao SZ. Design of electrocatalysts for oxygen-and hydrogen-involving energy conversion reactions. Chem. Soc. Rev. 2015;44:2060-2086.

56. Benck JD, Hellstern TR, Kibsgaard J, Chakthranont P, Jaramillo TF. Catalyzing the hydrogen evolution reaction (HER) with molybdenum sulfide nanomaterials. ACS Catal. 2014;4: 3957-3971.

57. Seh ZW, Kibsgaard J, Dickens CF, et al. Combining theory and experiment in electrocatalysis: Insights into materials design. Science 2017;355:eaad4998.

58. Staffell I, Scamman D, Abad AV, et al. The role of hydrogen and fuel cells in the global energy system. Energy Environ. Sci. 2019;12:463-491.

59. Brouwer J. On the role of fuel cells and hydrogen in a more sustainable and renewable energy future. Curr. Appl. Phys. 2010;10:S9-S17.

60. Kim KN, Lee SH, Kim H, Park YH, In S-I. Improved microbial electrolysis cell hydrogen production by hybridization with a $\mathrm{TiO}_{2}$ nanotube array photoanode. Energies 2018;11:3184.

61. Call D, Logan BE. Hydrogen production in a single chamber microbial electrolysis cell lacking a membrane. Environ. Sci. Technol. 2008;42:3401-3406.

62. Ditzig J, Liu H, Logan BE. Production of hydrogen from domestic wastewater using a bioelectrochemically assisted microbial reactor (BEAMR). Int. J. Hydrogen Energ. 2007;32:2296-2304.

63. Gadkari S, Shemfe M, Modestra JA, Mohan SV, Sadhukhan J. Understanding the interdependence of operating parameters in microbial electrosynthesis: a numerical investigation. Phys. Chem. Chem. Phys. 2019;21:10761-10772.

64. Zhou M, Gu T. The next breakthrough in microbial fuel cells and microbial electrolysis cells for bioenergy and bioproducts. J. Microb. Biochem. Technol. S. 2013;5:1-5.

65. Badwal SP, Giddey SS, Munnings C, Bhatt AI, Hollenkamp AF. Emerging electrochemical energy conversion and storage technologies. Front. Chem. 2014;2:79.

66. Kundu A, Sahu JN, Redzwan G, Hashim M. An overview of cathode material and catalysts suitable for generating hydrogen in microbial electrolysis cell. Int. J. Hydrogen Energ. 2013;38:1745-1757.

67. Jeremiasse AW. Cathode innovations for enhanced $\mathrm{H}_{2}$ production through microbial electrolysis [dissertation]. Wageningen: Wageningen University; 2011.

68. Selembo PA, Merrill MD, Logan BE. Hydrogen production with nickel powder cathode catalysts in microbial electrolysis cells. Int. J. Hydrogen Energ. 2010;35:428-437.

69. Zheng Y, Jiao Y, Zhu Y, et al. Hydrogen evolution by a metal-free electrocatalyst. Nat. Commun. 2014;5:1-8.

70. Lu S, Tan G, Zhu X. $\mathrm{H}_{2}$ Evolution Catalysts for Microbial Electrolysis Cells. In: Singh L, Mahapatra DM, Liu H, eds. Novel Catalyst Materials for Bioelectrochemical Systems: Fundamentals and Applications. ACS Publications; 2020. p. 27-43. 
71. Ivanov I, Ahn Y, Poirson T, Hickner MA, Logan BE. Comparison of cathode catalyst binders for the hydrogen evolution reaction in microbial electrolysis cells. Int. J. Hydrogen Energ. 2017;42:15739-15744.

72. Wang L, Chen Y, Ye Y, et al. Evaluation of low-cost cathode catalysts for high yield biohydrogen production in microbial electrolysis cell. Water. Sci. Technol. 2011;63:440-448.

73. Selembo PA, Merrill MD, Logan BE. The use of stainless steel and nickel alloys as low-cost cathodes in microbial electrolysis cells. J. Power. Sources. 2009;190:271-278.

74. Santos DM, Sequeira CA, Figueiredo JL. Hydrogen production by alkaline water electrolysis. Quim. Nova. 2013;36:1176-1193.

75. Ran F, Chen S. Advanced Nanomaterials for ElectrochemicalBased Energy Conversion and Storage. Elsevier; 2019.

76. Sapountzi FM, Gracia JM, Fredriksson HO, Niemantsverdriet $\mathrm{JH}$. Electrocatalysts for the generation of hydrogen, oxygen and synthesis gas. Prog. Energy. Combust. Sci. 2017;58:1-35.

77. Rashid MM, Al Mesfer MK, Naseem H, Danish M. Hydrogen production by water electrolysis: a review of alkaline water electrolysis, PEM water electrolysis and high temperature water electrolysis. Int. J. Eng. Adv. Technol. 2015;4:2249-8958.

78. Cardeña R, Cercado B, Buitrón G. Microbial Electrolysis Cell for Biohydrogen Production. In: Pandey A, Mohan SV, Chang JS, Hallenbeck PC, Larroche C, eds. Biohydrogen. Elsevier; 2019. p. 159-185.

79. Yan Z, Hitt JL, Turner JA, Mallouk TE. Renewable electricity storage using electrolysis. Proc. Natl. Acad. Sci. USA 2020;117:12558-12563.

80. Kadier A, Logroño W, Rai PK, et al. None-platinum electrode catalysts and membranes for highly efficient and inexpensive $\mathrm{H} 2$ production in microbial electrolysis cells (MECs): A review. Iran. J. Catal. 2017;7:89-102.

81. Hennebel T, Benner J, Clauwaert P, et al. Dehalogenation of environmental pollutants in microbial electrolysis cells with biogenic palladium nanoparticles. Biotechnol. Lett. 2011;33:89-95.

82. Grzeszczuk M, Poks P. The HER performance of colloidal Pt nanoparticles incorporated in polyaniline. Electrochim. Acta. 2000;45:4171-4177.

83. Rozendal RA, Hamelers HV, Molenkamp RJ, Buisman CJ. Performance of single chamber biocatalyzed electrolysis with different types of ion exchange membranes. Water. Res. 2007;41:1984-1994.

84. Sangeetha T, Guo Z, Liu W, et al. Cathode material as an influencing factor on beer wastewater treatment and methane production in a novel integrated upflow microbial electrolysis cell (Upflow-MEC). Int. J. Hydrogen Energ. 2016;41:2189-2196.

85. Sarkar S, Peter SC. An overview on Pd-based electrocatalysts for the hydrogen evolution reaction. Inorg. Chem. Front. 2018;5:2060-2080.

86. Kublanovsky V, Yapontseva Y. Electrocatalytic Properties of Molybdenum and Tungsten Alloys in the Hydrogen Evolution Reaction. In: Ray A, Mukhopadhyay I, Pati RK, eds. Electrocatalysts for Fuel Cells and Hydrogen Evolution-Theory to Design. IntechOpen; 2018. p. 95-117.

87. Lv Y, Wang X. Nonprecious metal phosphides as catalysts for hydrogen evolution, oxygen reduction and evolution reactions.
Catal. Sci. Technol. 2017;7:3676-3691.

88. Manuel M-F, Neburchilov V, Wang H, Guiot S, Tartakovsky B. Hydrogen production in a microbial electrolysis cell with nickel-based gas diffusion cathodes. J. Power Sources. 2010; 195:5514-5519.

89. Hu H, Fan Y, Liu H. Hydrogen production in single-chamber tubular microbial electrolysis cells using non-precious-metal catalysts. Int. J. Hydrogen Energ. 2009;34:8535-8542.

90. Harnisch F, Sievers G, Schröder U. Tungsten carbide as electrocatalyst for the hydrogen evolution reaction in $\mathrm{pH}$ neutral electrolyte solutions. Appl. Catal. B-Environ. 2009;89:455-458.

91. Vipond E, Rahman PK. Anaerobic digestion enhancement with microbial electrolysis cells: Is biomethane production the direction to go for commercialization? In: Pathak VM, Navneet eds. Handbook of Research on Microbial Tools for Environmental Waste Management. IGI Global; 2018. p. 259-269.

92. Rozendal RA, Jeremiasse AW, Hamelers HV, Buisman CJ. Hydrogen production with a microbial biocathode. Environ. Sci. Technol. 2008;42:629-634.

93. Lu L, Xing D, Ren N. Pyrosequencing reveals highly diverse microbial communities in microbial electrolysis cells involved in enhanced $\mathrm{H}_{2}$ production from waste activated sludge. Water Res. 2012;46:2425-2434.

94. Croese E, Pereira MA, Euverink G-JW, Stams AJ, Geelhoed JS. Analysis of the microbial community of the biocathode of a hydrogen-producing microbial electrolysis cell. Appl. Microbiol. Biotechnol. 2011;92:1083-1093.

95. Mohan SV, Agarwal L, Mohanakrishna G, et al. Firmicutes with iron dependent hydrogenase drive hydrogen production in anaerobic bioreactor using distillery wastewater. Int. J. Hydrogen Energ. 2011;36:8234-8242.

96. Shen R, Liu Z, He Y, et al. Microbial electrolysis cell to treat hydrothermal liquefied wastewater from cornstalk and recover hydrogen: Degradation of organic compounds and characterization of microbial community. Int. J. Hydrogen Energ. 2016;41:4132-4142.

97. Pisciotta JM, Zaybak Z, Call DF, Nam J-Y, Logan BE. Enrichment of microbial electrolysis cell biocathodes from sediment microbial fuel cell bioanodes. Appl. Environ. Microbiol. 2012;78: 5212-5219.

98. Cusick RD, Bryan B, Parker DS, et al. Performance of a pilot-scale continuous flow microbial electrolysis cell fed winery wastewater. Appl. Microbiol. Biotechnol. 2011;89:2053-2063.

99. Staszak-Jirkovský J, Malliakas CD, Lopes PP, et al. Design of active and stable Co-Mo-S x chalcogels as pH-universal catalysts for the hydrogen evolution reaction. Nat. Mat. 2016;15:197-203.

100. Xie J, Zhang H, Li S, et al. Defect-rich $\mathrm{MoS}_{2}$ ultrathin nanosheets with additional active edge sites for enhanced electrocatalytic hydrogen evolution. Adv. Mater. 2013;25:5807-5813.

101. Jaramillo TF, Jørgensen KP, Bonde J, et al. Identification of active edge sites for electrochemical $\mathrm{H}_{2}$ evolution from $\mathrm{MoS}_{2}$ nanocatalysts. Science 2007;317:100-102.

102. Sun Y, Alimohammadi F, Zhang D, Guo G. Enabling colloidal synthesis of edge-oriented $\mathrm{MoS}_{2}$ with expanded interlayer spacing for enhanced HER catalysis. Nano Lett. 2017;17: 1963-1969.

103. Liu J, Liu Y, Xu D, et al. Hierarchical "nanoroll” like 
$\mathrm{MoS}_{2} / \mathrm{Ti}_{3} \mathrm{C}_{2} \mathrm{Tx}$ hybrid with high electrocatalytic hydrogen evolution activity. Appl. Catal. B-Environ. 2019;241:89-94.

104. Chen YY, Zhang Y, Zhang X, et al. Self-templated fabrication of $\mathrm{MoNi}_{4} / \mathrm{MoO}_{3-\mathrm{x}}$ nanorod arrays with dual active components for highly efficient hydrogen evolution. Adv. Mater. 2017;29: 1703311.

105. Kadier A, Kalil MS, Abdeshahian P, et al. Recent advances and emerging challenges in microbial electrolysis cells (MECs) for microbial production of hydrogen and value-added chemicals. Renew. Sust. Energ. Rev. 2016;61:501-525.

106. Choi O, Sang B-I. Extracellular electron transfer from cathode to microbes: application for biofuel production. Biotechnol. Biofuels. 2016;9:11.

107. Schmitz S, Nies S, Wierckx N, Blank LM, Rosenbaum MA. Engineering mediator-based electroactivity in the obligate aerobic bacterium Pseudomonas putida KT2440. Front. Microbiol. 2015;6:284.

108. Kumar R, Singh L, Zularisam A. Exoelectrogens: recent advances in molecular drivers involved in extracellular electron transfer and strategies used to improve it for microbial fuel cell applications. Renew. Sust. Energ. Rev. 2016;56:1322-1336.

109. Sacco NJ, Bonetto MC, Cortón E. Isolation and characterization of a novel electrogenic bacterium, Dietzia sp. RNV-4. PLoS one. 2017;12:e0169955.

110. Tender LM, Reimers CE, Stecher HA, et al. Harnessing microbially generated power on the seafloor. Nat. Biotechnol. 2002;20:821-825.

111. Escapa A, San-Martín MI, Morán A. Potential use of microbial electrolysis cells in domestic wastewater treatment plants for energy recovery. Front. Energy Res. 2014;2:19.

112. Guo X, Liu J, Xiao B. Bioelectrochemical enhancement of hydrogen and methane production from the anaerobic digestion of sewage sludge in single-chamber membrane-free microbial electrolysis cells. Int. J. Hydrogen Energ. 2013;38: 1342-1347.

113. Kong F, Wang A, Cheng H, Liang B. Accelerated decolorization of azo dye Congo red in a combined bioanode-biocathode bioelectrochemical system with modified electrodes deployment. Bioresour. Technol. 2014;151:332-339.

114. Lal D. Microbes to generate electricity. Indian J. Microbiol. 2013;53:120-122.

115. Richardson DJ, Butt JN, Fredrickson JK, et al. The 'porin-cytochrome'model for microbe-to-mineral electron transfer. Mol. Microbiol. 2012;85:201-212.

116. Castelle C, Guiral M, Malarte G, et al. A new iron-oxidizing/ $\mathrm{O}_{2}$-reducing supercomplex spanning both inner and outer membranes, isolated from the extreme acidophile Acidithiobacillus ferrooxidans. J. Biol. Chem. 2008;283:25803-25811.

117. Shi L, Rosso KM, Zachara JM, Fredrickson JK. Mtr extracellular electron-transfer pathways in $\mathrm{Fe}$ (III)-reducing or $\mathrm{Fe}$ (II)-oxidizing bacteria: a genomic perspective. Biochem. Soc. Trans. 2012;40(6):1261-1267

118. Edwards MJ, White GF, Lockwood CW, et al. Structural modeling of an outer membrane electron conduit from a metal-reducing bacterium suggests electron transfer via periplasmic redox partners. J. Biol. Chem. 2018;293:8103-8112.

119. Jahan M, Tobe R, Mihara H. Characterization of a novel por- in-like protein, ExtI, from Geobacter sulfurreducens and its implication in the reduction of selenite and tellurite. Int. J. Mol. Sci. 2018;19:809.

120. Breuer M, Rosso KM, Blumberger J, Butt JN. Multi-haem cytochromes in Shewanella oneidensis MR-1: structures, functions and opportunities. J. R. Soc. Interface. 2015;12:20141117.

121. Arbour TJ, Gilbert B, Banfield JF. Diverse microorganisms in sediment and groundwater are implicated in extracellular redox processes based on genomic analysis of bioanode communities. Front. Microbiol. 2020;11:1694.

122. Otero FJ, Chan CH, Bond DR. Identification of different putative outer membrane electron conduits necessary for Fe (III) citrate, Fe (III) oxide, Mn (IV) oxide, or electrode reduction by Geobacter sulfurreducens. J. Bacteriol. 2018;200:e00347-00318.

123. Santos TC, Silva MA, Morgado L, Dantas JM, Salgueiro CA. Diving into the redox properties of Geobacter sulfurreducens cytochromes: a model for extracellular electron transfer. Dalton Trans. 2015;44:9335-9344.

124. Inoue $\mathrm{K}$, Leang $\mathrm{C}$, Franks $\mathrm{AE}$, et al. Specific localization of the c-type cytochrome OmcZ at the anode surface in current-producing biofilms of Geobacter sulfurreducens. Environ. Microbiol. Rep. 2011;3:211-217.

125. Kato Marcus A, Torres CI, Rittmann BE. Conduction-based modeling of the biofilm anode of a microbial fuel cell. Biotechnol. Bioeng. 2007;98:1171-1182.

126. Rampelotto PH, Extremophiles and extreme environments, in, Multidisciplinary Digital Publishing Institute. Life 2013 3:482-485.

127. Horikoshi K. Alkaliphiles: some applications of their products for biotechnology. Microbiol. Mol. Biol. Rev. 1999;63:735-750.

128. Cao Y, Mu H, Liu W, et al. Electricigens in the anode of microbial fuel cells: pure cultures versus mixed communities. Microb. Cell Fact. 2019;18:1-14.

129. Pinck S, Ostormujof LM, Teychené S, Erable B. Microfluidic Microbial Bioelectrochemical Systems: An Integrated Investigation Platform for a More Fundamental Understanding of Electroactive Bacterial Biofilms. Microorganisms 2020; 8:1841.

130. Vieille C, Zeikus GJ. Hyperthermophilic enzymes: sources, uses, and molecular mechanisms for thermostability. Microbiol. Mol. Biol. Rev. 2001;65:1-43.

131. Rathinam NK, Bibra M, Salem DR, Sani RK. Thermophiles for biohydrogen production in microbial electrolytic cells. Bioresour. Technol. 2019;277:171-178.

132. Krishna KV, Swathi K, Hemalatha M, Mohan SV. Bioelectrocatalyst in Microbial Electrochemical Systems and Extracellular Electron Transport. In: Mohan SV, Varjani S, Pandey A, eds. Microbial Electrochemical Technology. Elsevier; 2019. p. 117-141.

133. Oren A. Microbial life at high salt concentrations: phylogenetic and metabolic diversity. Saline Syst. 2008;4:2.

134. Zeng F, Wu Y, Bo L, et al. Coupling of electricity generation and denitrification in three-phase single-chamber MFCs in high-salt conditions. Bioelectrochemistry 2020;133:107481.

135. Borjas Z, Ortiz JM, Aldaz A, Feliu J, Esteve-Núñez A. Strategies for reducing the start-up operation of microbial electrochemical treatments of urban wastewater. Energies 2015;8: 
14064-14077.

136. Ramírez-Vargas CA, Prado A, Arias CA, et al. Microbial electrochemical technologies for wastewater treatment: principles and evolution from microbial fuel cells to bioelectrochemicalbased constructed wetlands. Water 2018;10:1128.

137. Yee MO, Deutzmann J, Spormann A, Rotaru A-E. Cultivating electroactive microbes - from field to bench. Nanotechnology 2020;31:174003.

138. Marsili E, Baron DB, Shikhare ID, et al. Shewanella secretes flavins that mediate extracellular electron transfer. Proc. Natl. Acad. Sci. USA 2008;105:3968-3973.

139. Torres CI, Krajmalnik-Brown R, Parameswaran P, et al. Selecting anode-respiring bacteria based on anode potential: phylogenetic, electrochemical, and microscopic characterization. Environ. Sci. Technol. 2009;43:9519-9524.

140. Premier GC, Kim JR, Michie I, Dinsdale RM, Guwy AJ. Automatic control of load increases power and efficiency in a microbial fuel cell. J. Power Sources. 2011;196:2013-2019.

141. Blasco-Gómez R, Batlle-Vilanova P, Villano M, et al. On the edge of research and technological application: a critical review of electromethanogenesis. Int. J. Mol. Sci. 2017;18:874.

142. Patil SA, Hägerhäll C, Gorton L. Electron transfer mechanisms between microorganisms and electrodes in bioelectrochemical systems. Bioanal. Rev. 2012;4:159-192.

143. Rotaru A-E, Shrestha PM, Liu F, et al. Direct interspecies electron transfer between Geobacter metallireducens and Methanosarcina barkeri. Appl. Environ. Microbiol. 2014;80: 4599-4605.

144. Sasaki K, Morita M, Sasaki D, et al. A bioelectrochemical reactor containing carbon fiber textiles enables efficient methane fermentation from garbage slurry. Bioresour. Technol. 2011;102:6837-6842.

145. Lee B, Park J-G, Shin W-B, Tian D-J, Jun H-B. Microbial communities change in an anaerobic digestion after application of microbial electrolysis cells. Bioresour. Technol. 2017;234: 273-280.

146. Demirel B, Scherer P. The roles of acetotrophic and hydrogenotrophic methanogens during anaerobic conversion of biomass to methane: a review. Rev. Environ. Sci. Biotechnol. 2008;7:173-190.

147. Cheng S, Xing D, Call DF, Logan BE. Direct biological conversion of electrical current into methane by electromethanogenesis. Environ. Sci. Technol. 2009;43:3953-3958.

148. Bo T, Zhu X, Zhang L, et al. A new upgraded biogas production process: coupling microbial electrolysis cell and anaerobic digestion in single-chamber, barrel-shape stainless steel reactor. Electrochem. Commun. 2014;45:67-70.

149. Gao Y, Sun D, Dang Y, et al. Enhancing biomethanogenic treatment of fresh incineration leachate using single chambered microbial electrolysis cells. Bioresour. Technol. 2017;231:129-137.

150. Zhen G, Kobayashi T, Lu X, Xu K. Understanding methane bioelectrosynthesis from carbon dioxide in a two-chamber microbial electrolysis cells (MECs) containing a carbon biocathode. Bioresour. Technol. 2015;186:141-148.

151. Siegert M, Yates MD, Spormann AM, Logan BE. Methanobacterium dominates biocathodic archaeal commun- ities in methanogenic microbial electrolysis cells. ACS Sustain. Chem. Eng. 2015;3:1668-1676.

152. Liu F, Rotaru A-E, Shrestha PM, et al. Promoting direct interspecies electron transfer with activated carbon. Energ. Environ. Sci. 2012;5:8982-8989.

153. Rotaru A-E, Shrestha PM, Liu F, et al. A new model for electron flow during anaerobic digestion: direct interspecies electron transfer to Methanosaeta for the reduction of carbon dioxide to methane. Energy Environ. Sci. 2014;7:408-415.

154. Baek G, Kim J, Kim J, Lee C. Role and potential of direct interspecies electron transfer in anaerobic digestion. Energies 2018;11:107.

155. Lovley DR. Syntrophy goes electric: direct interspecies electron transfer. Annu. Rev. Microbiol. 2017;71:643-664.

156. Torres CI, Marcus AK, Lee H-S, et al. A kinetic perspective on extracellular electron transfer by anode-respiring bacteria. FEMS Microbiol. Rev. 2010;34:3-17.

157. Hernandez ME, Kappler A, Newman DK. Phenazines and other redox-active antibiotics promote microbial mineral reduction. Appl. Environ. Microbiol. 2004;70:921-928.

158. Newman DK, Kolter R. A role for excreted quinones in extracellular electron transfer. Nature 2000;405:94-97.

159. Von Canstein H, Ogawa J, Shimizu S, Lloyd JR. Secretion of flavins by Shewanella species and their role in extracellular electron transfer. Appl. Environ. Microbiol. 2008;74:615-623.

160. Gorby YA, Yanina S, McLean JS, et al. Electrically conductive bacterial nanowires produced by Shewanella oneidensis strain MR-1 and other microorganisms. Proc. Natl. Acad. Sci. USA. 2006;103:11358-11363.

161. Reguera G, McCarthy KD, Mehta T, et al. Extracellular electron transfer via microbial nanowires. Nature 2005;435:1098-1101.

162. Ter Heijne A, Geppert F, Sleutels TH, et al. Mixed culture biocathodes for production of hydrogen, methane, and carboxylates. In: Harnisch F, Holtmann D, eds. Bioelectrosynthesis. Springer; 2017. p. 203-229.

163. Enzmann F, Mayer F, Rother M, Holtmann D. Methanogens: biochemical background and biotechnological applications. AMB Express. 2018;8:1-22.

164. Logan BE, Regan JM. Electricity-producing bacterial communities in microbial fuel cells. Trends Microbiol. 2006;14:512-518.

165. Kadier A, Simayi Y, Kalil MS, Abdeshahian P, Hamid AA. A review of the substrates used in microbial electrolysis cells (MECs) for producing sustainable and clean hydrogen gas. Renew. Energy. 2014;71:466-472.

166. Montpart N, Rago L, Baeza JA, Guisasola A. Hydrogen production in single chamber microbial electrolysis cells with different complex substrates. Water Res. 2015;68:601-615.

167. Villano M, Ralo C, Zeppilli M, Aulenta F, Majone M. Influence of the set anode potential on the performance and internal energy losses of a methane-producing microbial electrolysis cell. Bioelectrochemistry 2016;107:1-6.

168. Heidrich E, Dolfing J, Scott K, et al. Production of hydrogen from domestic wastewater in a pilot-scale microbial electrolysis cell. Appl. Microbiol. Biotechnol. 2013;97:6979-6989.

169. Saito T, Mehanna M, Wang X, et al. Effect of nitrogen addition on the performance of microbial fuel cell anodes. Bioresour. Technol. 2011;102:395-398. 
170. Sun R, Zhou A, Jia J, et al. Characterization of methane production and microbial community shifts during waste activated sludge degradation in microbial electrolysis cells. Bioresour. Technol. 2015;175:68-74.

171. Carlotta-Jones DI, Purdy K, Kirwan K, Stratford J, Coles SR. Improved hydrogen gas production in microbial electrolysis cells using inexpensive recycled carbon fibre fabrics. Bioresour. Technol. 2020;304:122983.

172. Feng Q, Song Y-C, Bae B-U. Influence of applied voltage on the performance of bioelectrochemical anaerobic digestion of sewage sludge and planktonic microbial communities at ambient temperature. Bioresour. Technol. 2016;220:500-508.

173. Baca M, Singh S, Gebinoga M, et al. Microbial Electrochemical Systems with Future Perspectives using Advanced Nanomaterials and Microfluidics. Adv. Energy Mater. 2016;6:1600690.

174. Nakamura R, Kai F, Okamoto A, Hashimoto K. Mechanisms of long-distance extracellular electron transfer of metal-reducing bacteria mediated by nanocolloidal semiconductive iron oxides. J. Mater. Chem. 2013;1:5148-5157.

175. Yan W, Sun F, Liu J, Zhou Y. Enhanced anaerobic phenol degradation by conductive materials via EPS and microbial community alteration. Chem. Eng. J. 2018;352:1-9.

176. Sevda S, Sharma S, Joshi C, et al. Biofilm formation and electron transfer in bioelectrochemical systems. Environ. Technol. Rev. 2018;7:220-234.

177. Bian B, Bajracharya S, Xu J, Pant D, Saikaly PE. Microbial electrosynthesis from $\mathrm{CO} 2$ : Challenges, opportunities and perspectives in the context of circular bioeconomy. Bioresour. Technol. 2020;302:122863.

178. Olabi A, Wilberforce T, Sayed ET, et al. Recent progress of graphene based nanomaterials in bioelectrochemical systems. Sci. Total. Environ. 2020;749:141225.

179. Speranza G. The Role of Functionalization in the Applications of Carbon Materials: An Overview. C-J. Carbon Res. 2019;5:84.

180. Kadier A, Jiang Y, Lai B, et al. Biohydrogen production in microbial electrolysis cells from renewable resources. In: Konur O, eds. Bioenergy and Biofuels. CRC Press; 2018. p. 331-356.

181. Feng Q, Song Y-C. Surface modification of a graphite fiber fabric anode for enhanced bioelectrochemical methane production. Energ. Fuel. 2016;30:6467-6474.

182. Zhen G, Kobayashi T, Lu X, Kumar G, Xu K. Biomethane recovery from Egeria densa in a microbial electrolysis cell-assisted anaerobic system: performance and stability assessment. Chemosphere 2016;149:121-129.

183. Wei J, Liang $P$, Huang X. Recent progress in electrodes for microbial fuel cells. Bioresour. Technol. 2011;102:9335-9344.

184. Zakaria BS, Dhar BR. Progress towards catalyzing electro-methanogenesis in anaerobic digestion process: Fundamentals, process optimization, design and scale-up considerations. Bioresour. Technol. 2019;289:121738.

185. Rozendal RA, Hamelers HV, Rabaey K, Keller J, Buisman CJ. Towards practical implementation of bioelectrochemical wastewater treatment. Trends Biotechnol. 2008;26:450-459.

186. Saheb-Alam S, Singh A, Hermansson M, et al. Effect of start-up strategies and electrode materials on carbon dioxide reduction on biocathodes. Appl. Environ. Microbiol. 2018;84:e02242-17. 187. Moreno R, San-Martín M, Escapa A, Morán A. Domestic wastewater treatment in parallel with methane production in a microbial electrolysis cell. Renew. Energy. 2016;93:442-448.

188. Gajaraj S, Huang Y, Zheng P, Hu Z. Methane production improvement and associated methanogenic assemblages in bioelectrochemically assisted anaerobic digestion. Biochem. Eng. J. 2017;117:105-112.

189. Siegert M, Li X-F, Yates MD, Logan BE. The presence of hydrogenotrophic methanogens in the inoculum improves methane gas production in microbial electrolysis cells. Front. Microbiol. 2015;5:778.

190. Salvador AF, Martins G, Melle-Franco M, et al. Carbon nanotubes accelerate methane production in pure cultures of methanogens and in a syntrophic coculture. Environ. Microbiol. 2017;19:2727-2739.

191. Zhen G, Lu X, Kobayashi T, Kumar G, Xu K. Promoted electromethanosynthesis in a two-chamber microbial electrolysis cells (MECs) containing a hybrid biocathode covered with graphite felt (GF). Chem. Eng. J. 2016;284:1146-1155.

192. Liu D, Roca-Puigros M, Geppert F, et al. Granular carbon-based electrodes as cathodes in methane-producing bioelectrochemical systems. Front. Bioeng. Biotechnol. 2018;6:78.

193. Guo K, Prévoteau A, Patil SA, Rabaey K. Engineering electrodes for microbial electrocatalysis. Curr. Opin. Biotechnol. 2015;33:149-156.

194. Guo Z, Thangavel S, Wang L, et al. Efficient methane production from beer wastewater in a membraneless microbial electrolysis cell with a stacked cathode: the effect of the cathode/anode ratio on bioenergy recovery. Energ. Fuel. 2017;31:615-620.

195. De Vrieze J, Gildemyn S, Arends JB, et al. Biomass retention on electrodes rather than electrical current enhances stability in anaerobic digestion. Water Res. 2014;54:211-221.

196. Park J-G, Lee B, Shi P, Kim Y, Jun H-B. Effects of electrode distance and mixing velocity on current density and methane production in an anaerobic digester equipped with a microbial methanogenesis cell. Int. J. Hydrogen Energ. 2017;42: 27732-27740.

197. Sugnaux M, Happe M, Cachelin CP, et al. Cathode deposits favor methane generation in microbial electrolysis cell. Chem. Eng. J. 2017;324:228-236.

198. Hou Y, Zhang R, Luo H, et al. Microbial electrolysis cell with spiral wound electrode for wastewater treatment and methane production. Process Biochem. 2015;50:1103-1109.

199. Xafenias N, Mapelli V. Performance and bacterial enrichment of bioelectrochemical systems during methane and acetate production. Int. J. Hydrogen Energ. 2014;39:21864-21875.

200. Rozendal RA, Hamelers HV, Euverink GJ, Metz SJ, Buisman CJ. Principle and perspectives of hydrogen production through biocatalyzed electrolysis. Int. J. Hydrogen Energ. 2006;31: 1632-1640.

201. Katz E, Willner I. Integrated nanoparticle-biomolecule hybrid systems: synthesis, properties, and applications. Angew. Chem. Int. Ed. 2004;43:6042-6108.

202. Verma A, Stellacci F. Effect of surface properties on nanoparticle-cell interactions. Small 2010;6:12-21. 
203. Noori MT, Vu MT, Ali RB, Min B. Recent advances in cathode materials and configurations for upgrading methane in bioelectrochemical systems integrated with anaerobic digestion. Chem. Eng. J. 2020;392:123689.

204. Kim K-R, Kang J, Chae K-J. Improvement in methanogenesis by incorporating transition metal nanoparticles and granular activated carbon composites in microbial electrolysis cells. Int. J. Hydrogen Energ. 2017;42:27623-27629.

205. Vu MT, Noori MT, Min B. Conductive magnetite nanoparticles trigger syntrophic methane production in single chamber microbial electrochemical systems. Bioresour. Technol. 2020;296:122265.

206. Liu W, Cai W, Guo Z, et al. Microbial electrolysis contribution to anaerobic digestion of waste activated sludge, leading to accelerated methane production. Renew. Energ. 2016;91:334-339.

207. Katuri KP, Werner CM, Jimenez-Sandoval RJ, et al. A novel anaerobic electrochemical membrane bioreactor (AnEMBR) with conductive hollow-fiber membrane for treatment of low-organic strength solutions. Environ. Sci. Technol. 2014;48:12833-12841.

208. Kadier A, Simayi Y, Abdeshahian P, et al. A comprehensive review of microbial electrolysis cells (MEC) reactor designs and configurations for sustainable hydrogen gas production. Alex. Eng. J. 2016;55:427-443.

209. Villano M, Monaco G, Aulenta F, Majone M. Electrochemically assisted methane production in a biofilm reactor. J. Power Sources. 2011;196:9467-9472.

210. Ding A, Yang Y, Sun G, Wu D. Impact of applied voltage on methane generation and microbial activities in an anaerobic microbial electrolysis cell (MEC). Chem. Eng. J. 2016;283: 260-265.

211. Wang K, Sheng Y, Cao H, Yan K, Zhang Y. Impact of applied current on sulfate-rich wastewater treatment and microbial biodiversity in the cathode chamber of microbial electrolysis cell (MEC) reactor. Chem. Eng. J. 2017;307:150-158.

212. Yu Z, Leng X, Zhao S, et al. A review on the applications of microbial electrolysis cells in anaerobic digestion. Bioresour. Technol. 2018;255:340-348.

213. Varanasi JL, Veerubhotla R, Pandit S, Das D. Biohydrogen Production Using Microbial Electrolysis Cell: Recent Advances and Future Prospects. In: Mohan SV, Varjani S, Pandey A, eds. Microbial Electrochemical Technology. Elsevier; 2019. p. 843-869.

214. Omidi H, Sathasivan A. Optimal temperature for microbes in an acetate fed microbial electrolysis cell (MEC). Int. Biodeterior. Biodegrad. 2013;85:688-692.

215. Clauwaert P, Verstraete W. Methanogenesis in membraneless microbial electrolysis cells. Appl. Microbiol. Biotechnol. 2009;82:829-836.

216. Zhu G, Wu T, Jha AK, et al. Review of bio-hydrogen production and new application in the pollution control via microbial electrolysis cell. Desalin. Water. Treat 2014;52:5413-5421.

217. Merrill MD, Logan BE. Electrolyte effects on hydrogen evolution and solution resistance in microbial electrolysis cells. J. Power Sources. 2009;191:203-208.

218. Torres CI, Marcus AK, Rittmann BE. Kinetics of consumption of fermentation products by anode-respiring bacteria. Appl.
Microbiol. Biotechnol. 2007;77:689-697.

219. Rousseau R, Etcheverry L, Roubaud E, et al. Microbial electrolysis cell (MEC): Strengths, weaknesses and research needs from electrochemical engineering standpoint. Appl. Energy. 2020;257:113938.

220. Guo H, Kim Y. Stacked multi-electrode design of microbial electrolysis cells for rapid and low-sludge treatment of municipal wastewater. Biotechnol. Biofuels 2019;12:23.

221. Katuri KP, Ali M, Saikaly PE. The role of microbial electrolysis cell in urban wastewater treatment: integration options, challenges, and prospects. Curr. Opin. Biotechnol. 2019;57: 101-110.

222. Kadier A, Jain P, Lai B, et al. Biorefinery perspectives of microbial electrolysis cells (MECs) for hydrogen and valuable chemicals production through wastewater treatment. Biofuel. Res. J. 2020;7:1128-1142.

223. Chakraborty I, Sathe S, Khuman C, Ghangrekar M. Bioelectrochemically powered remediation of xenobiotic compounds and heavy metal toxicity using microbial fuel cell and microbial electrolysis cell. Mater. Sci. Eng. Technol. 2020;3:104-115.

224. Hua T, Li S, Li F, Zhou Q, Ondon BS. Microbial electrolysis cell as an emerging versatile technology: a review on its potential application, advance and challenge. J. Chem. Technol. Biotechnol. 2019;94:1697-1711.

225. Enzmann F, Holtmann D. Rational Scale-Up of a methane producing bioelectrochemical reactor to $50 \mathrm{~L}$ pilot scale. Chem. Eng. Sci. 2019;207:1148-1158.

226. Cerrillo M, Viñas M, Bonmatí A. Anaerobic digestion and electromethanogenic microbial electrolysis cell integrated system: Increased stability and recovery of ammonia and methane. Renew. Energy. 2018;120:178-189.

227. Cai W, Liu W, Yang C, et al. Biocathodic methanogenic community in an integrated anaerobic digestion and microbial electrolysis system for enhancement of methane production from waste sludge. ACS Sustain. Chem. Eng. 2016;4:4913-4921.

228. Zhi Z, Pan Y, Lu X, et al. Electrically regulating co-fermentation of sewage sludge and food waste towards promoting biomethane production and mass reduction. Bioresour. Technol. 2019;279:218-227.

229. Xu X-J, Wang W-Q, Chen C, et al. The effect of PBS on methane production in combined MEC-AD system fed with alkaline pretreated sewage sludge. Renew. Energy. 2020;152:229-236.

230. Xiao L, Liu F, Lichtfouse E, et al. Methane production by acetate dismutation stimulated by Shewanella oneidensis and carbon materials: An alternative to classical $\mathrm{CO}_{2}$ reduction. Chem. Eng. J. 2020;389:124469.

231. Yin Q, Zhu X, Zhan G, et al. Enhanced methane production in an anaerobic digestion and microbial electrolysis cell coupled system with co-cultivation of Geobacter and Methanosarcina. J. Environ. Sci. 2016;42:210-214.

232. Zeppilli M, Villano M, Aulenta F, et al. Effect of the anode feeding composition on the performance of a continuous-flow methane-producing microbial electrolysis cell. Environ. Sci. Pollut. Res. 2015;22:7349-7360.

233. Park J, Lee B, Tian D, Jun H. Bioelectrochemical enhancement of methane production from highly concentrated food waste 
in a combined anaerobic digester and microbial electrolysis cell. Bioresour. Technol. 2018;247:226-233.

234. Zeppilli M, Cristiani L, dell'Armi E, Majone M. Bioelectromethanogenesis reaction in a tubular Microbial Electrolysis Cell (MEC) for biogas upgrading. Renew. Energy. 2020;158:23-31

235. Huang L, Jiang L, Wang Q, et al. Cobalt recovery with simultaneous methane and acetate production in biocathode microbial electrolysis cells. Chem. Eng. J. 2014;253:281-290.
236. Siegert M, Yates MD, Call DF, et al. Comparison of nonprecious metal cathode materials for methane production by electromethanogenesis. ACS Sustain. Chem. Eng. 2014;2: 910-917.

237. Van Eerten-Jansen MC, Veldhoen AB, Plugge CM, et al. Microbial community analysis of a methane-producing biocathode in a bioelectrochemical system. Archaea 2013;2013: 481784 